\title{
Mistletoe, Viscum album (Santalaceae), in Britain and Ireland: a discussion and review of current status and trends
}

\author{
Jonathan Briggs \\ Stonehouse, Gloucestershire, UK
}

Corresponding author: jonathanbriggs@mistletoe.org.uk

This pdf constitutes the Version of Record published on 30

\begin{abstract}
The status of Viscum album L. (Mistletoe) in Britain and Ireland is discussed and current trends reviewed. An overview of life-cycle is given, including discussion of dispersal, germination and host connection, all aspects important in understanding status and trends. A summary of hosts and habitats is followed by a review of distribution; the long-established pattern in the south-west midlands plus recent and ongoing changes. The biodiversity value of mistletoe for other species is discussed. The seasonal mistletoe trade, its history and implications, is outlined. Some current conservation, control and planting projects are described. A brief summary of toxicity and medicinal uses is given. Concluding remarks outline various research opportunities; particularly those that would help understand and set a baseline to measure current and future trends.
\end{abstract}

Keywords: monitoring; climate change; parasite; seed vector; haustorium; keystone species

\section{Introduction}

Mistletoe Viscum album L. is one of our most recognisable native plants, as well as being one of the most specialised and most misunderstood. This paper sets out to review numerous aspects of the species in the British Isles, covering a broad range of background issues. These include an outline of life cycle, discussions on distribution plus emerging needs relating to monitoring, conservation and control. There is also a discussion of the seasonal mistletoe trade and how this developed from the mid19th century. The aim is to raise awareness of current status and, hopefully, inspire future research. Research is certainly needed as the species' status here does seem to be changing. The background material presented here should help understanding how these changes may be happening.

This is by no means an exhaustive review. A technical biological review of the species will soon be available in a forthcoming paper in the Biological Flora of the British Isles series (Thomas et al., in prep.). From continental Europe there is also a wide-ranging existing account in the Biological Flora of Central Europe series (Zuber, 2004) and a more recent general European account by Krasylenko et al. (2020). There is a review volume (Bussing, 2000) that covers some biology alongside 
medicinal accounts. A much older, but very comprehensive, account is given in an 800-page monograph (in German) by von Tubeuf (1923).

The paper draws on my own observations over 40 years of informal mistletoe study, which have included local studies in Gloucestershire, Herefordshire and Worcestershire, co-ordinating the BSBI and Plantlife Mistletoe Survey in the 1990s, and working with wildlife groups, carrying out conservation plantings and monitoring across the country. In addition, I have been closely involved with mistletoe harvesting and marketing groups, including helping establish the Tenbury Wells Mistletoe Festival. I still work with traditional orchard groups on mistletoe management and on practical and marketing work with groups and individuals cultivating the species.

\section{Studies in Britain}

There have been very few overall studies of $V$. album in Britain and Ireland, but there have numerous studies in continental Europe. For the British Isles the main studies, primarily relating to distribution, have been Perring (1973) reporting on the 1970s BSBI national mistletoe survey and Briggs (1999) reporting on the follow-up 1990 s mistletoe survey. The latter survey, run jointly by BSBI and Plantlife was never written up formally because of perceived problems with data accuracy, especially host identification, relating to records sent in by the general public. It was an early example of what would now be termed a citizen science project, with flaws, particularly recorder effort, as discussed by Rich (2000). There was a later proposal to rationalise the data (Briggs, 2007) but this was not progressed. General results of the 1990s project are discussed later in this paper.

Other recent accounts of $V$. album including my own reviews of distribution changes, biodiversity value and general biology (e.g. Briggs, 1996, 2011a, 2012, 2019). A review of the species' status in Ireland was compiled by Nelson (2008). Recent specialist national studies include the reviews of $V$. album on oak (Box, 2000, 2019). There have been various local studies of $V$. album, some of which are discussed in the references above and later in this paper.

The distribution studies all highlight the abundance of $V$. album across much of the south west English midlands and the southern Welsh borders (hereafter referred to as the 'main range'). Elsewhere there are scattered records and isolated populations, some known for a century or more (Fig. 1). This pattern, and emerging changes in it, is discussed more fully later in the paper. However, as will be seen, recording spatial distribution only is arguably inadequate in assessing status of $V$. album. As an obligate hemi-parasite of trees there is a need to gather host and infection density data too. Increasing evidence of changes in distribution and, crucially, infection density per host throughout Europe can only be understood if quantity assessments, using repeatable systems, are included in studies. Likely causes of change, as will be seen, include climate change, changes in bird berry vectors, habitat management neglect by man and/or deliberate planting by man.

The association with apple orchards, the loss of which was a primary concern of the 1990s project, now seems much less important, possibly even naive. $V$. album is doing very well in Britain despite (and in some places because, albeit perhaps temporarily, ) apple orchard decline. The species is rare in many places, but that has probably always been the case. In areas where it is scarce it is valued, and often 
planted. In areas where it is common it can become a pest. Overall, across Britain and Ireland, the species is not endangered. However, the annual Christmas harvest and trade (mostly from neglected apple orchards in its main range) may be threatened as those orchards continue to decline.

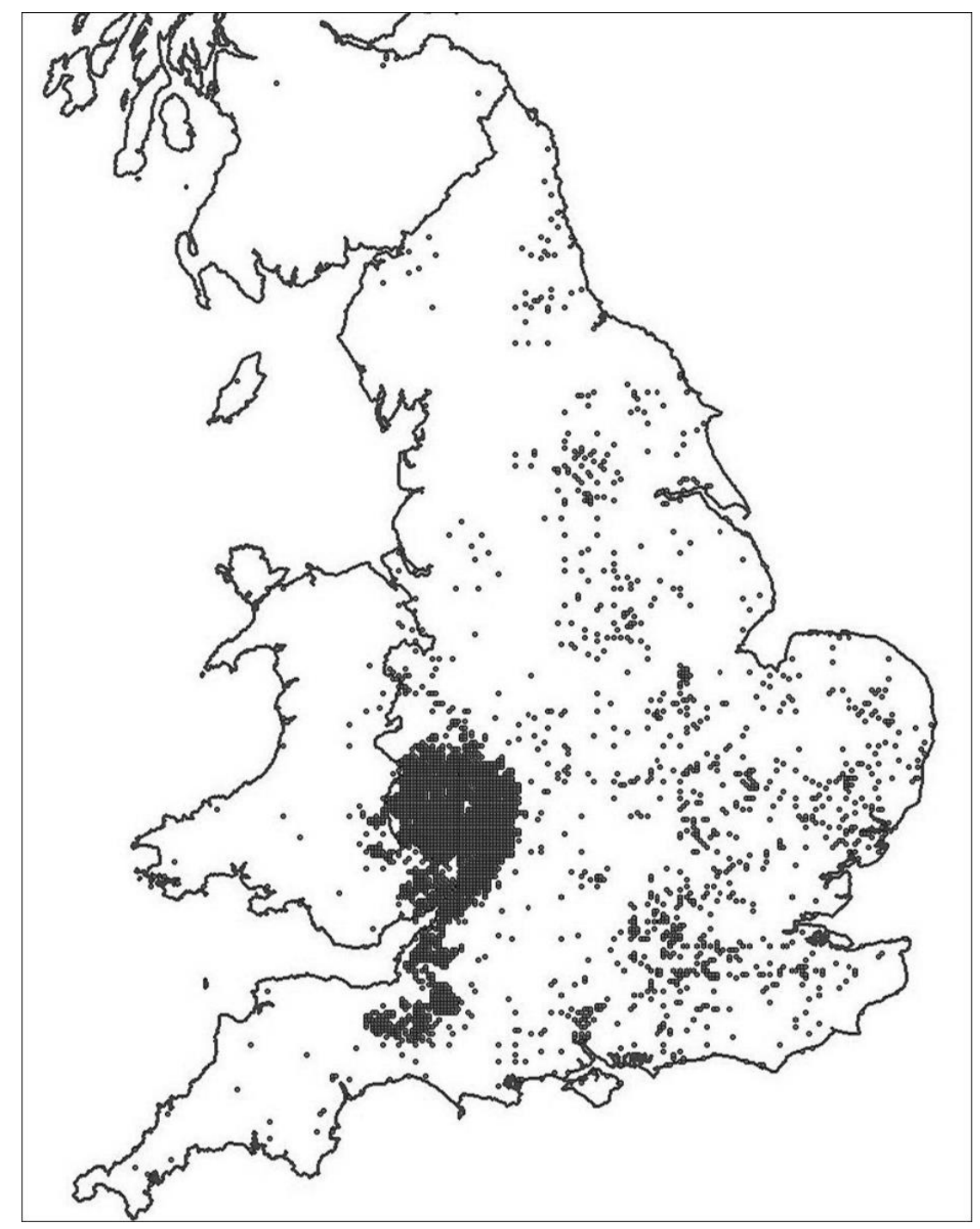

Figure 1. Distribution of Viscum album subsp. album (mistletoe) in England and Wales, re-mapped from the 1990s Plantlife/BSBI data described in Briggs (1999).

\section{Peculiarities and misunderstandings}

Viscum album is a very unusual plant, not just in being parasitic but also in its form (Fig. 2) and seasonality. It is a long-lived perennial evergreen, parasitic only on deciduous (in the British Isles) hosts. As such it 'reappears' (Fig. 3), larger each year, following host leaf fall every autumn, and then remains the only greenery on the tree until spring. The growth form is geometric, and on undamaged growths, becomes spherical. All leaves, in distinctively-shaped pairs, are on the outside of the sphere. Berries are white, a most unusual colour (our only white-berried native plant) and ripen to that colour during the midwinter months. These attributes are all 
unusual - unique even - and, in combination, readily account for why the plant has been celebrated as a winter plant of special qualities for millennia.

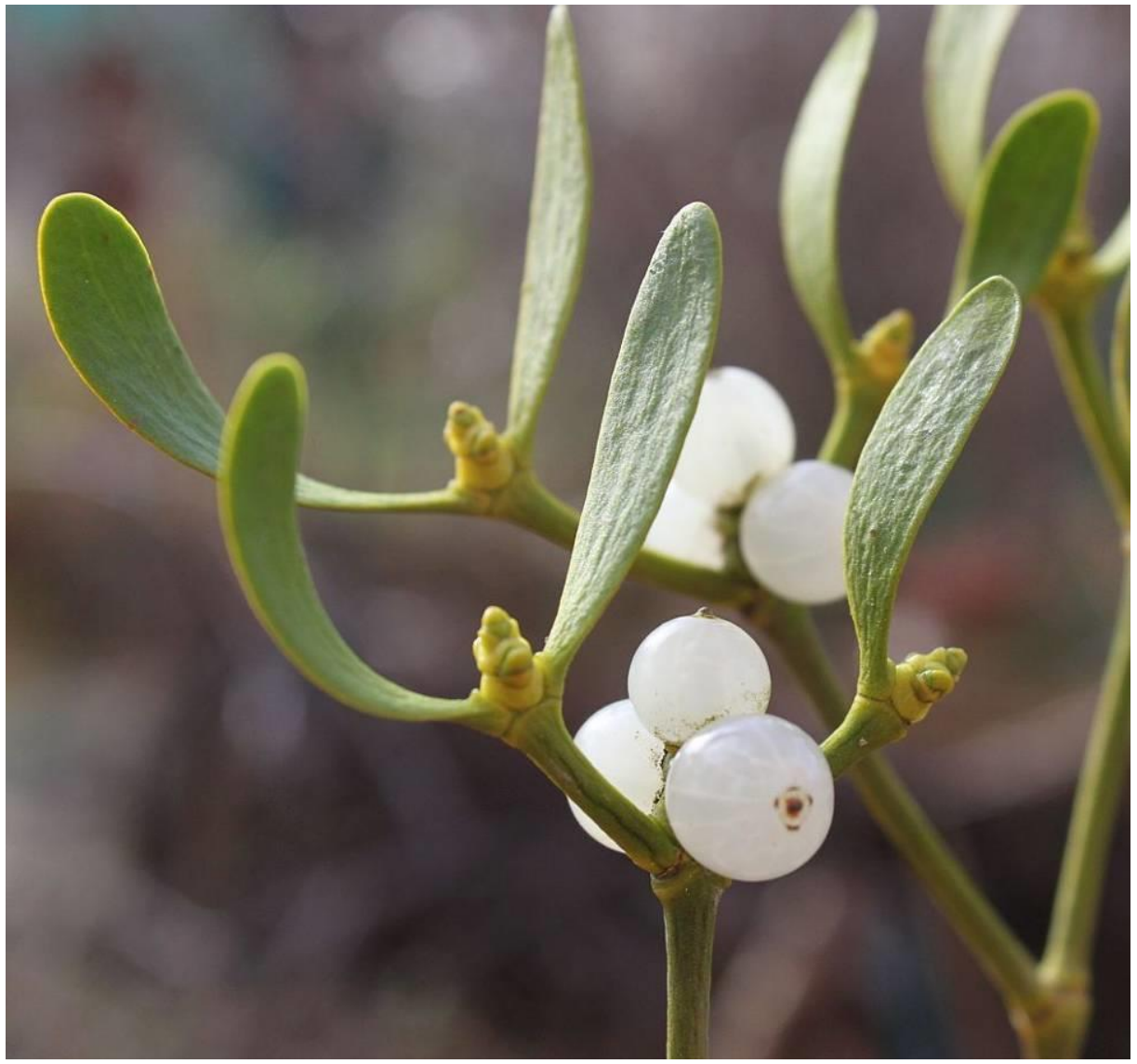

Figure 2. Viscum album, in fruit showing annual growth pattern.

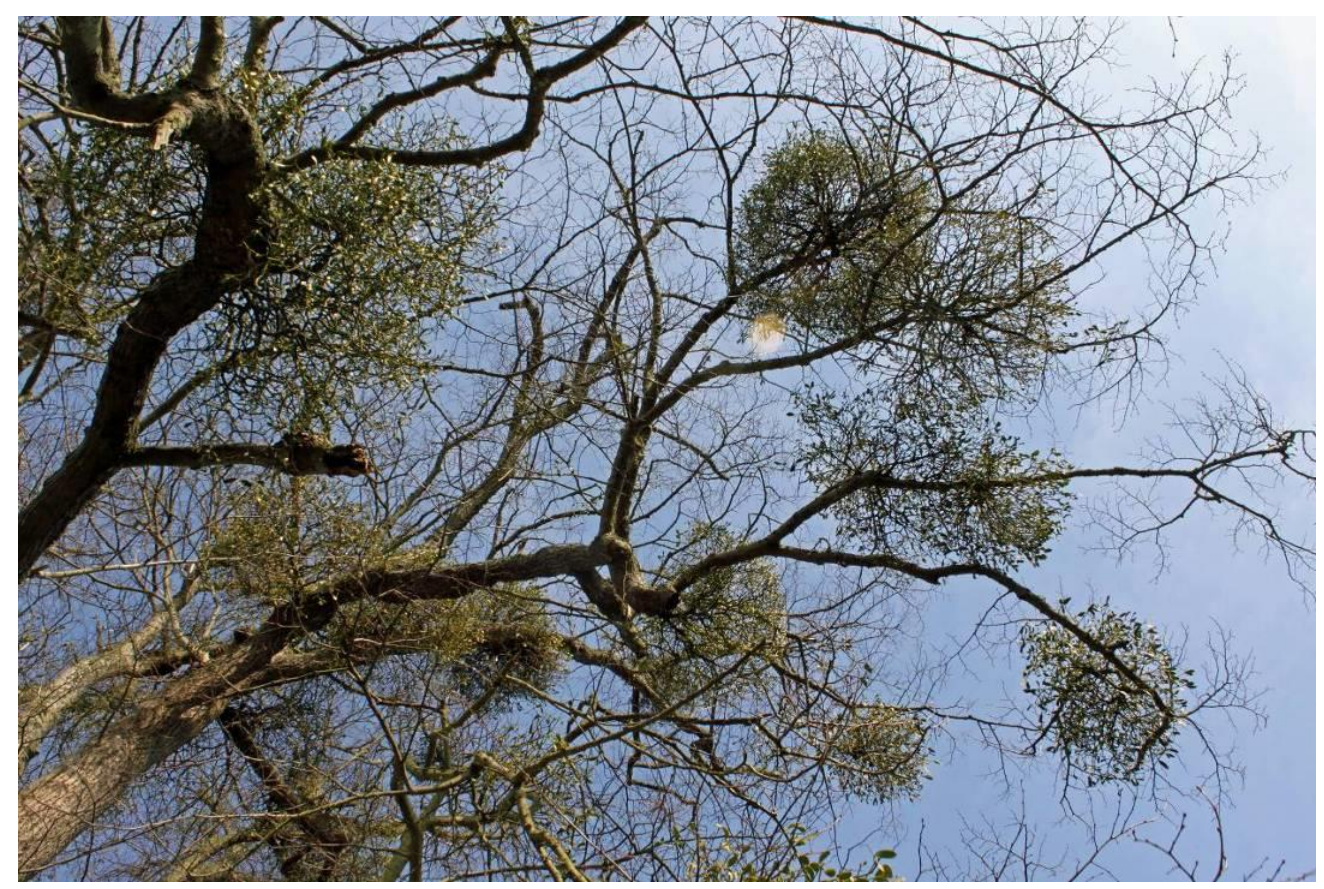

Figure 3. Viscum album growths after host leaf-fall. 
It is often associated with fertility symbolism and heal-all medicines but those are just a few of its alleged properties. It features in Roman, Greek, Norse and Druidic myths, and is considered the 'golden bough' of legend. Sir James Frazer's epic multi-volume monograph on ancient religion and magic was named The Golden Bough (Frazer, 1890) in deference to it. This paper is not the place to recount these traditions, other than to highlight how, even today, they still alter our understanding and studies of the plant.

The association with oak is one example of this. Viscum album on other hosts is just as interesting, arguably much more so, but oak still dominates many discussions. The background to this is the tale that ancient British druids worshipped mistletoe on oak, cutting it in midwinter with golden sickles for some ritual or medicinal use. This story, based on one account by Pliny the Elder in his Natural History in the first century AD, may be entirely apocryphal and/or not even about Britain. Viscum album rarely grows on oak (Box, 2019) and Pliny's writings are notorious for much inaccuracy. Regardless of this Pliny's account was re-written and re-told continually across two millennia. Many traditional herbals, for example, state that mistletoe from oak is best (despite it being practically unobtainable). The most influential re-telling however, was during the 18th century revival/reinvention of druidry, spearheaded by William Stukeley and others. This really established the $V$. album and oak ritual as 'fact' and set the scene for confused later analysis, particularly historical accounts.

Archaeologists for example, sometimes overly strive to find druidic links. Early examples, from the early $19^{\text {th }}$ century, are perhaps directly influenced by the druid revival. Three round nodules found in a Yorkshire tumulus excavated in 1834 were interpreted at the time as $V$. album berries, the associated burial being thought to be about $500 \mathrm{BC}$, close to the time of the druids. Analysis in 2009 (Edwards et al., 2010) found these 'berries' to be simply urinary stones and the burial to date from about $2000 \mathrm{BC}$, precluding the involvement of druids.

The desire to make a link has persisted to recent times. Viscum album material discovered in the stomach of Lindow Man, the bog body excavated in Cheshire in 1984 , led to much speculation of links with druids. Dating evidence suggested he died between $2 \mathrm{BC}$ to $\mathrm{AD} 119$, a period associated with druidry and this, plus other remains found, led to fanciful suggestions that he was a ritually-slaughtered 'druid prince' (Ross \& Robins, 1989). More sober analysis points out that, since only four pollen grains of $V$. album were found, many other explanations are more likely, including accidental ingestion (Joy, 2009). There is little convincing archaeological evidence of druids at all, let alone a link with $V$. album (Hutton, 2009). Roy Vickery summarises the situation succinctly, suggesting that due to Pliny's account "more nonsense has been written about mistletoe than any other British plant" (Vickery 1995). I hope that this paper helps debunk some of that nonsense, much of which is more recent than ancient writings, and does not add any.

\section{Taxonomy}

Viscum album is in the Santalaceae. Until recently it was in a separate family Viscaceae, a large family of mistletoe species which, along with the related Loranthaceae (also all mistletoes), is largely tropical and subtropical in distribution. Europe is at the northern edge of the range of both these mistletoe families, with 
just a few species present. These include, in addition to $V$. album, $V$. cruciatum Sieber ex Boiss, Arceuthobium oxycedri (DC) M.Bieb. (both native to Mediterranean coastal countries) and, from the Loranthaceae, Loranthus europaeus Jacq. in central southern Europe.

Four subspecies of $V$. album are recognised across Europe:

- subsp. album L. (syn var. platyspermum Keller). Parasitising numerous dicotyledonous hosts

- subsp. abietis (Wiesb.) Abrom. Parasitising Abies hosts

- subsp. austriacum (Wiesb.) Vollm. Parasitising Pinus, Larix and Picea hosts

- subsp. creticum N.Böhling, Greuter, Raus, B.Snogerup, Snogerup \& Zuber.

Parasitising Pinus hosts.

Of these, only $V$. album subsp. album occurs as far north as Britain. Within mainland Europe the distribution of the first three subspaces all overlap to some extent. Subspecies creticum is endemic to Crete. The subspecies are virtually identical to each other, often only reliably determined as adult plants by their host. Seeds from each will, however, only successfully infect the correct host(s).

\section{Flowering, pollination and annual increments}

This account summarises the key features of the life cycle that affect distribution, dispersal and growth. More detail will be available in the forthcoming Biological Flora account (Thomas et al., in prep.) and can also be found in Zuber (2004). It is important to note that most of the critical stages take place in winter, with berryripening, seed dispersal and flowering for the next season all coinciding with the mid to late winter months.

Flowers open in February and March, having developed in bud slowly over most of the previous year. The species is dioecious but, since plants often grow adjoining each other (or even on each other epiparasitically) one 'clump' can sometimes be a mixture of both genders. The most visible flowers develop from terminal buds, situated between the pair of terminal leaves. There are also flower buds at the nodes below the leaf pairs. Flowers are small, sessile and green, inconspicuous even when fully open. Male flowers comprise 4 tepals with pollen shed by pores on the tepal surface. Female flowers, smaller than the male, have four tepals surrounding a simple style (Fig. 4). These simple structures, opening early in the year, suggest wind might be the primary pollination mechanism. However, though some wind pollination does occur, most studies have confirmed that insect pollination is more important, with nectar produced by both male and female flowers.

The majority of the pollinating insects are Diptera, particularly Dasyphora and similar small species from other genera. Hymenoptera, including honeybees Apis mellifera L. are also involved. On a warm sunny February afternoon, the loud buzzing of early flying bees can often be heard from $V$. album clumps on apple trees. A few pollination studies have been undertaken in Britain, including Kay (1989) and Hatton (1964). Other studies across Europe are referenced in Zuber (2004). The importance of these early spring insects in economic terms, ensuring berried plants at Christmas, is discussed by Ollerton et al. (2016).

After pollination the berries develop very slowly. Oval and green at first, they gradually expand in size to become spherical and opaque white by late autumn. 
They ripen to a translucent white by late November. Even then they may not be fully ripe, as the seeds germinate best in February and March, a full 12 months after original pollination.

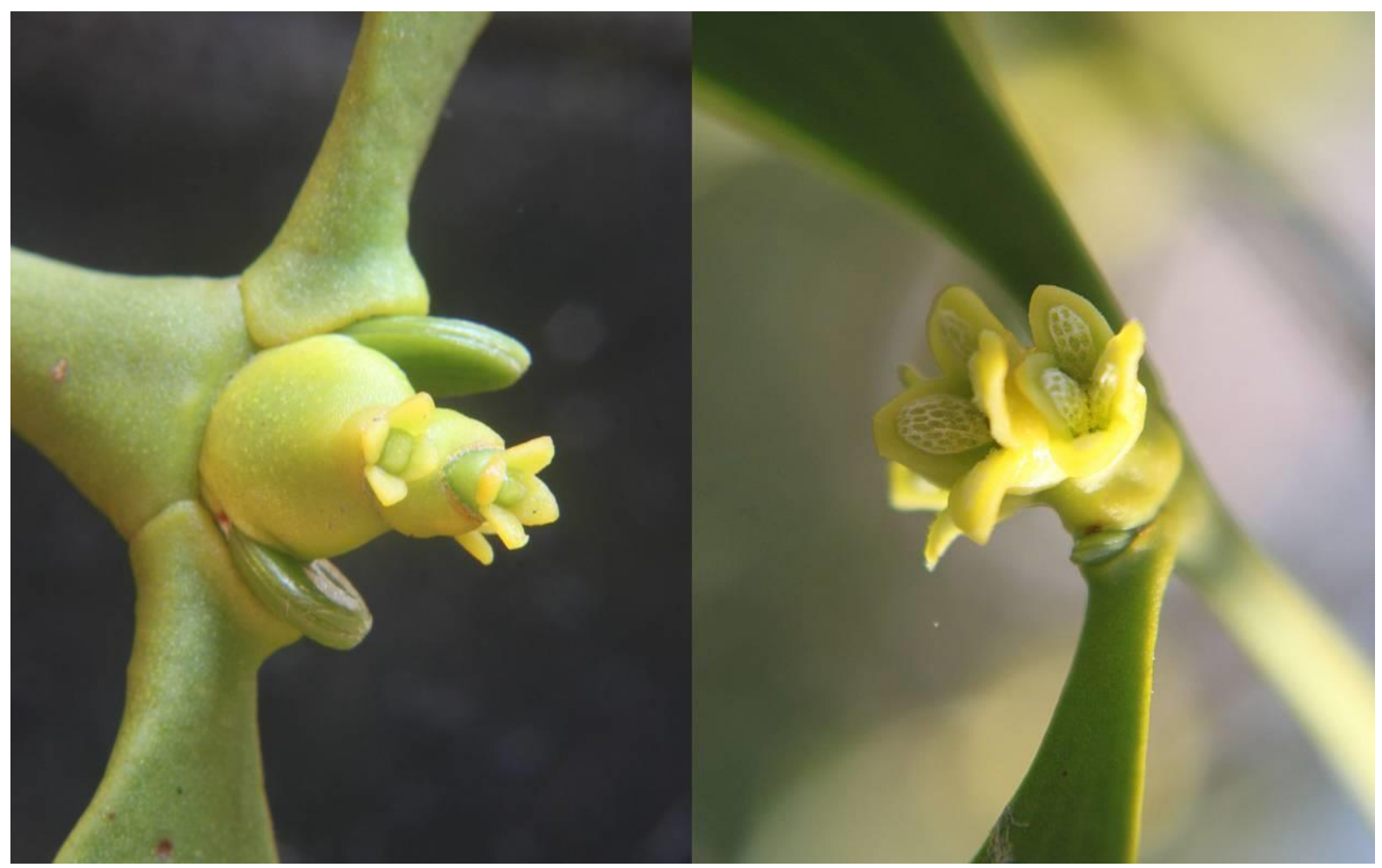

Figure 4. Viscum album flowers, female (left) and male (right).

Whilst the berries are developing each plant also begins a precise annual growth increment. Two new branches are produced either side of the terminal flowers (initial growths are visible in Fig. 4). These two new internodes each produce one new pair of leaves. Each new internode and its leaf pair grow slowly through the summer months to become full sized by late summer. Between these new leaf pairs new flower buds develop during the summer, to open the following year.

This dichasial pattern means the numbers of branches, leaf pairs and flowers all double every year. This annual exponential growth in leaf numbers has implications, discussed later, for water relations and the host. The precise pattern of growth also ensures the plant grows outwardly by the same extent on all sides. This explains, after a few initial years of asymmetric growth when first established, the spherical growths seen in older specimens. Each will be growing outwardly by an equal amount each year. The age of an intact large growth can be estimated by counting the internodes. They can easily be 10 to 20 years old, often very much older.

This growth strategy also means that by the winter, when deciduous hosts have lost their leaves, each plant is encased entirely in perfect new leaves, with the berries forming in the axils behind them. Older leaves, behind the new growths, tend to fall in their second season, often in late summer when $V$. album leaf litter appears on the ground below infections. The distinctive terminal leaf pairs, often forming a 
horse-shoe in shape, become the dominant feature until the berries whiten. Leaf size can vary considerably, with some plants having leaves twice the size of others. There is some anecdotal evidence that this size variation may be related to particular hosts rather than particular $V$. album genotypes.

When the berries ripen to white they become the dominant visual feature for the female plants, especially when seen in the low sun of a midwinter day. Their translucency means that the seeds, one in each berry, can be clearly seen through the berry skin. They are cushioned within the berry in a sticky jelly-like mesocarp, the sticky 'viscin' that gives the genus its name. The seed itself is a flattened chlorophyllous structure, often visibly green through the berry skin. Each seed contains one or more embryos, usually just one or two but sometimes three or four.

\section{Seed dispersal}

Dispersal relies entirely on animal vectors, mainly birds but also, significantly in some areas, man. The behaviour of bird vectors, particularly the distance dispersed and the dispersal sites, is a factoring limiting $V$. album spread, accounting for why many populations are so isolated. Our mistletoe's dependence on vectors both for pollination and seed dispersal was noted by Darwin as the 'principal check 'on its success (Stauffer, 1975).

This is a problem faced by all mistletoes worldwide, whose seeds need to be not merely transported but to be placed on a suitable host. Some have specialists; birds that feed primarily on mistletoe berries and distribute them efficiently (see e.g. Watson, 2013). Others, including those for $V$. album, tend to be generalists, birds that feed on numerous other berry sources but happen to also eat $V$. album (see e.g. Mellado \& Zamora, 2014, studying dispersal of V. album subsp. austriacum in Spain).

A complicating factor for $V$. album is the nature of the berries; bright white in colour and containing a very sticky material. Some studies suggest that many birds fail to recognise the white (as opposed to orange, red or black) berries as food. Many of the birds that do will be put off trying again because of the natural viscosity, which makes the seeds sticky and difficult to manipulate in the beak. Viscin from the berries is so glutinous it was once a primary ingredient in birdlime, a substance made to trap birds. With such constraints it is perhaps unsurprising that there are no dedicated vectors for $V$. album, not in Britain anyway.

The primary vector in Britain has been, certainly in popular perception, the Mistle Thrush Turdus viscivorus $L$, a species actually named for eating $V$. album. These thrushes will certainly readily devour the berries, along with many other related thrushes, particularly Fieldfares $T$. pilaris $L$. However, despite the name, the Mistle Thrush in Britain and Ireland can scarcely be considered a $V$. album specialist, as it feeds on many other berries and, unlike $V$. album, is distributed across the whole country. Most British Mistle Thrushes will never encounter mistletoe. Their English name, an anglicisation of the scientific name (Lockwood, 1984) is, therefore, rather misleading. The scientific name, an original Linnean name, may be less so, as Mistle Thrushes in continental Europe, where V. album is widely distributed, encounter mistletoe far more often than their British counterparts. The species is considered as a genuine $V$. album specialist for some areas. Mistle Thrush 
distribution in Hungary has been directly linked to V. album abundance (Varga et al.,2014)

Other bird vectors for V. album include Waxwing Bombycilla garrulous L. and more intriguingly, Blackcaps Sy/via atricapilla (L.), whose overwintering populations in Britain are a recent (see summary in Van Doren, 2021) phenomenon that has significant implications for $V$. album spread.

Most of the bird vectors, certainly the Thrushes and Blackcaps, are territorial feeders. When they have chosen a suitable food source they will guard it against incomers until they have finished eating. This behaviour for Thrushes with $V$. album in Britain is documented in a series of observations by Snow \& Snow (1988). This territorialism has implications for berry spread, since the waste, in the form of the seeds, tends to be moved only short distances, the bird only leaving the berry source unattended for a minute or so.

There are two ways for birds to spread the seeds, largely depending on the size of the bird. Thrushes tend to be endozoochorous dispersers, consuming the whole berry, seed included, and excreting the seeds later. In contrast Blackcaps are ectozoochorous dispersers, consuming only the berry skin and pulp, not the seed, which is wiped off the beak. The differences are important.

A thrush, having consumed a gutful of $V$. album berries over 20-30 minutes, and needing to excrete without leaving the food source undefended, will fly a short distance, usually in the same or an adjoining tree, to relieve itself. The location will often be a dedicated latrine area, from which it can quickly return to gorge on more berries. The excreted seeds, in a mass of semi-digested sticky viscin pulp, will fall onto any surface below that latrine area. This may be the ground, or a fence railing, or a branch. Any seeds actually hitting the branch will stick on. But often, even if the excretion hits a branch, most seeds will dangle in a sticky thread below (Fig. 5).

For Blackcaps there is similar territorial behaviour, but with a more positive outcome for the seeds. These birds take one berry at a time, squeezing it in their beak to push out the seed so that they consume only the pulp. The seed, being sticky, tends to stick frustratingly to the beak and so the birds usually move a short distance, again close to the food source and often in the same tree, and wipe the sticky seed off on a surface before returning immediately for the next berry. The wiping surface is, usually, a branch (Fig. 6). Blackcap-dispersed seeds are therefore far more likely to be placed firmly on a branch, with very few wasted, than Thrushdispersed seeds.

The inefficiency of thrush-dispersed seeds is easily demonstrated by observation within a mistletoe-laden apple orchard in late winter. Thrush latrines (Fig. 5) are easily found, branches with multiple strings of dangling sticky seeds, with only the top few seeds actually on the bark. Mellado \& Zamora (2014) studying bird dispersal of $V$. album subsp. austriacum found that, of the 11 bird vectors identified, thrushes, although the major consumer, were the least efficient at placing seeds in viable locations. 


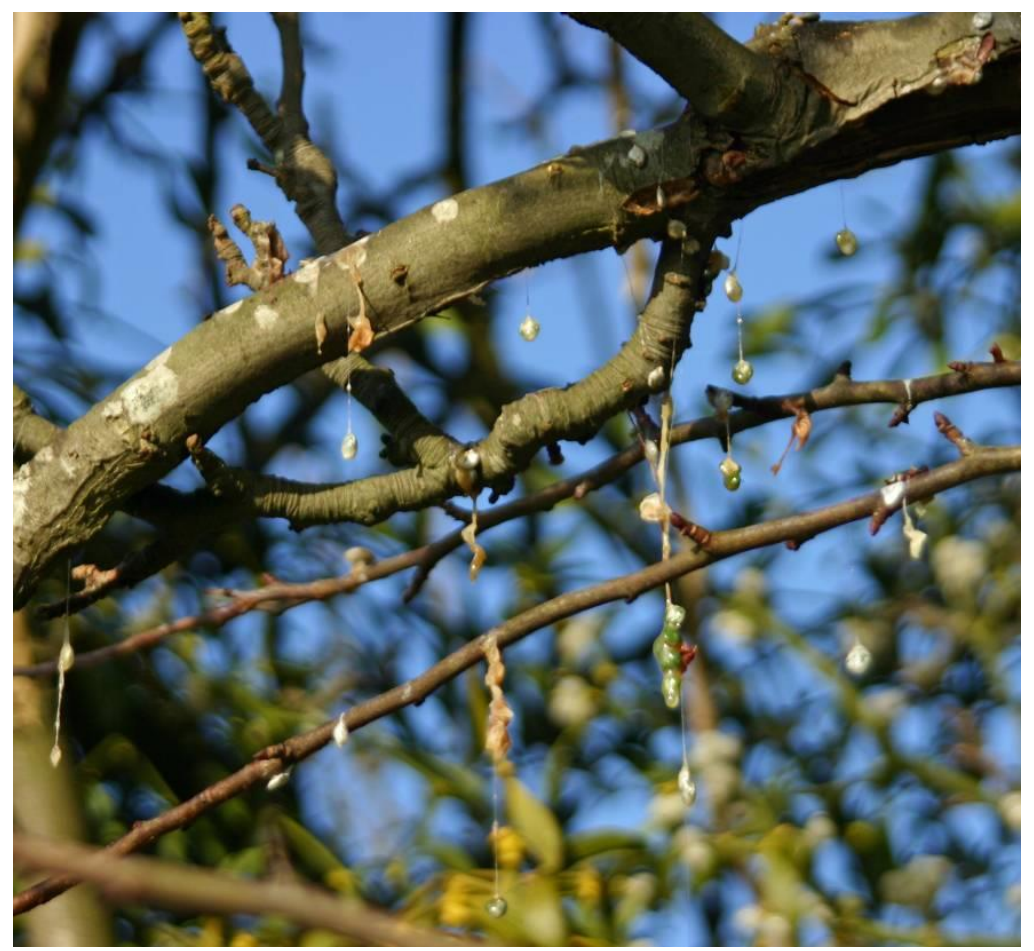

Figure 5. A Mistle Thrush latrine in a mistletoe-laden apple tree, showing how each excretion of semi-digested berry mucous hangs from branches with most seeds dangling, with no chance of survival, below the branch.

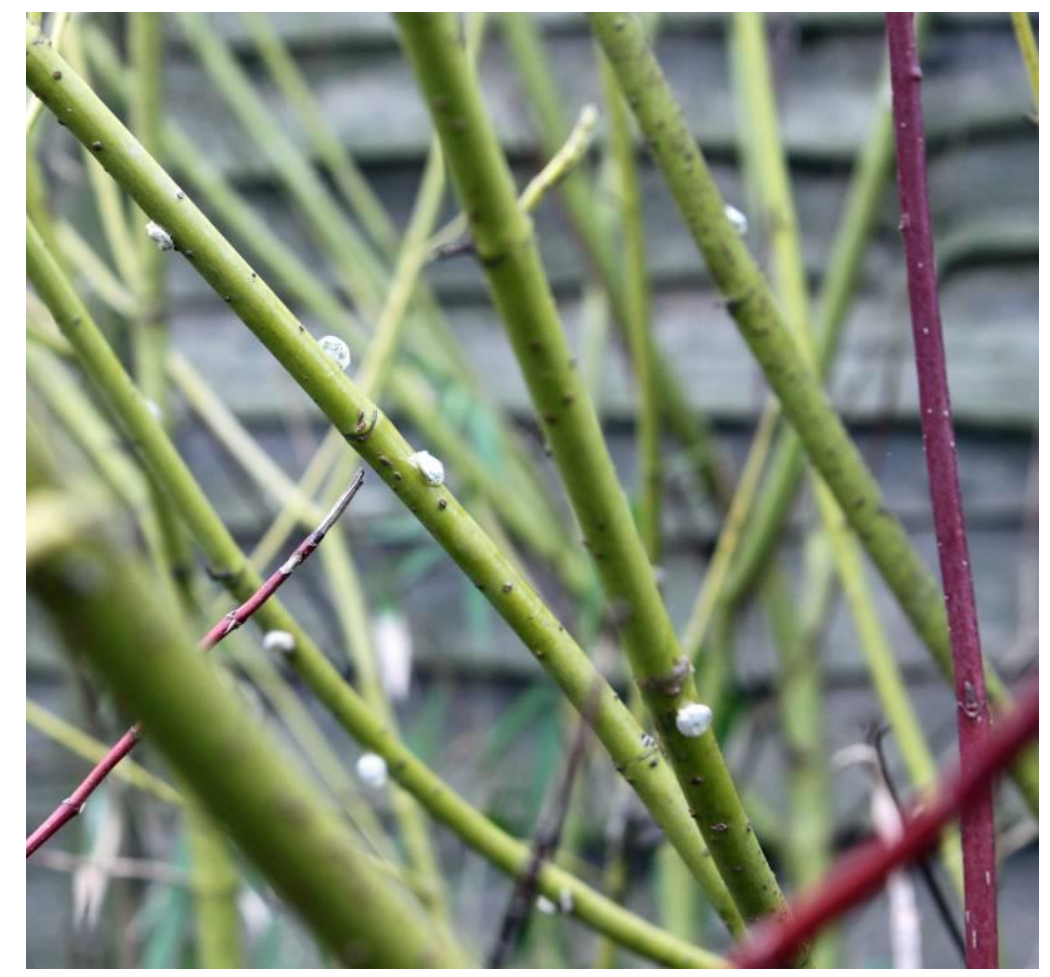

Figure 6. A Blackcap beak-wiping area (on Cornus sanguinea L.) created by a bird feeding on mistletoe on an adjoining tree, showing how each seed is attached to a branch (albeit in this case a relatively unsuitable host species). 
Berry consumption by waxwings is similar to thrushes, also endozoochorous and spreading locally, but they are unlikely to be a significant factor for $V$. album in Britain. The significance of the recent increases in overwintering Blackcap is discussed later. Other recent vectors in Britain including the Ring-necked Parakeets Psittacula krameri (Scopoli), well-established now in some urban areas including Bushy and Home Parks in Richmond, Surrey, where V. album is common. Though they have been observed consuming $V$. album berries the dispersal implications, if any, are not yet known.

Other species sometimes mentioned for $V$. album include many smaller birds such as tits, but these tend to peck at berries ineffectually. They will, however, readily consume the bare seeds placed on branches by the other birds. Wood Pigeons Columba palumbus L. are often seen feeding within $V$. album growths and might be berry feeders. They may, however, be simply grazing the leaves, which often show neat bite damage and if they do consume the berries the seeds may not survive passage through their more muscular gizzards.

Dispersal distance, as mentioned above, is an important element in $V$. album spread. For the territorial vectors it tends to be in the same or adjoining trees. This is especially so for the seed wipers. But, for the endozoochorous dispersers, there is at least some potential for distance spread, particularly at the end of a feeding session when the food source is abandoned and no longer guarded. The final mistletoe excretion from a thrush, after a long period gorging on berries, might be several kilometres away. It may be inefficiently placed but, if successful, will enable new colonies. Most placings, being local, lead to intensification of existing colonies.

\section{Germination and seedlings}

Viscum album seeds tend to germinate best in early to mid spring, either because they are immature before or simply because they need higher temperatures to germinate. This seasonality often coincides neatly with bird dispersal of the seeds, as most birds, even the frequent $V$. album consumers, tend not to eat the berries in quantity until late winter onwards, consuming other, more palatable berries from other plants first. Berries that are not eaten will remain on the parent plant, often well into the summer, with the seeds within them germinating, helplessly, inside the translucent structure.

The seeds that have been dispersed germinate quite readily, on whatever surface or structure they end up on (or even in mid-air when dangling in a dried thread of a thrush turd. This ease of germination might seem surprising as there is a popular belief, often repeated in gardening texts, that $V$. album seeds are difficult to germinate. This is incorrect. A high rate of germination is actually essential, as most seeds will not end up on a suitable host branch. Germination success can be seen readily near a mistletoe-laden apple tree in April and May, where bird sown seed, even on fences, tree guard timbers etc can be easily found germinating. Stanton et al. (2010) investigated germination rates for $V$. album seeds gathered from fragmented habitats in Belgium, expecting to find decreased germination due to loss of genetic diversity. Instead they found high germination, consistent with the need to compensate for unsuitable locations. A study reported by Heide-Jorgensen (2008) investigating establishment of Viscum minimum Harv. looked at germination on a 
variety of suitable and less suitable hosts. Germination was high on all, but establishment only occurred on suitable hosts.

One likely explanation for gardening texts getting this so wrong is that most suggest (even some early reports by this author) that the seed should be inserted in a slit in bark and/or bound on with raffia or similar. Germination rates of seeds treated like this will indeed be low, or non-existent, as the exclusion of light will kill them. $V$. album seeds are photosynthetic whilst still in the berry and it is wellestablished (e.g. Guerin, 1903, von Tubeuf, 1923, Showler, 1974, Salle, 1983, Zuber, 2004) that they need light throughout the germination period.

This need for light is easily confirmed by simple experimentation. In 2014 I conducted a basic demonstration with seeds kept in differing periods of darkness. Seeds were extracted from berries in March and samples placed on the bare surface of a number of open petri dishes, each with about 10 per surface. Individual dishes were brought out of darkness in batches over six weeks. Seeds brought out in weeks 0,1 and 2 germinated readily (Fig. 7), but those left in darkness until weeks 3, 4, 5 and 6 mostly failed to germinate at all (Briggs, 2014). Seeds can, it should be noted, survive in light for weeks outside the berry so their age, for this exercise, is not a factor.

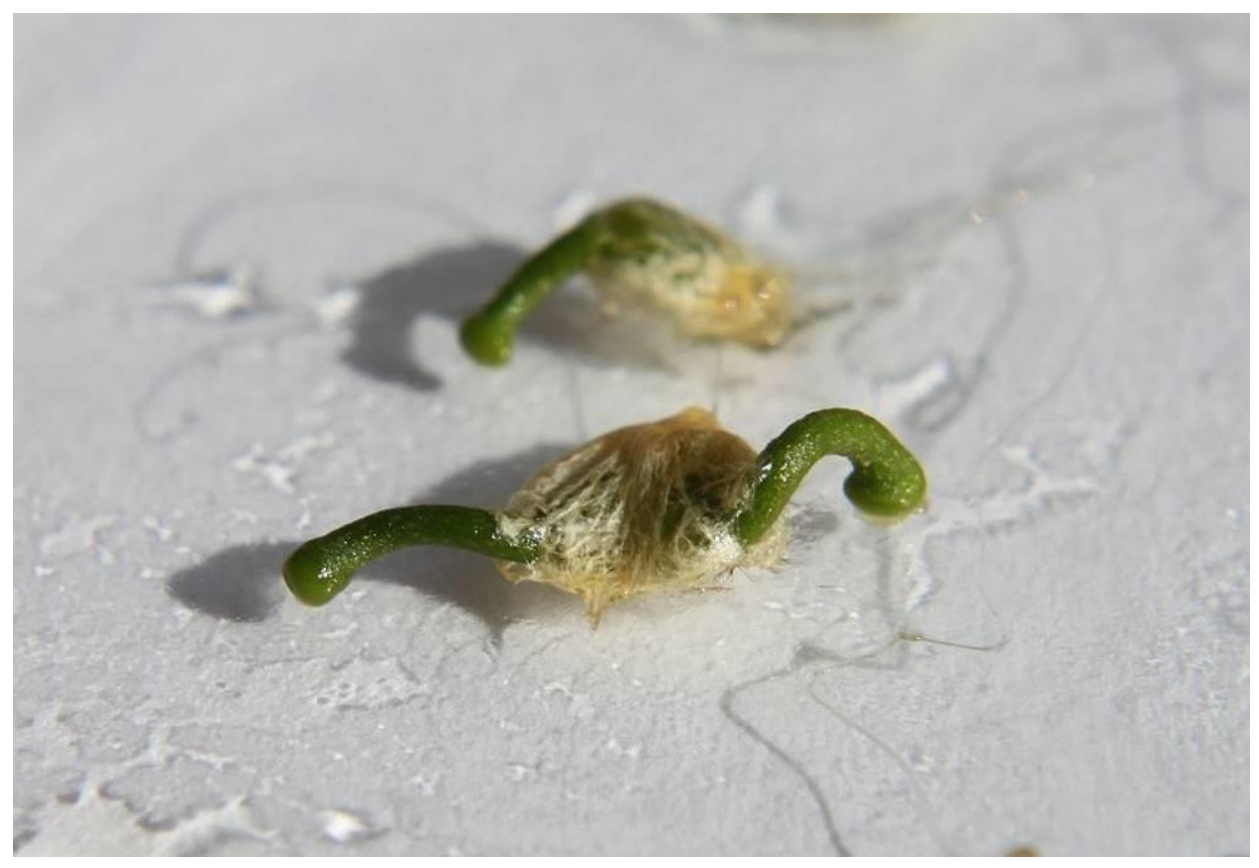

Figure 7. Germinating mistletoe seeds, on a petri dish indoors. The foreground seed has two embryos and therefore two hypocotyls, the rear one only one.

The photosynthetic seeds and emerging growths are, at this stage, independent plants and not yet parasitic. They will live for months like this, though some will be lost to grazing by invertebrates and birds. The shoots are hypocotyls, one per embryo, with two being a frequent number. These negatively phototrophic shoots curl to touch the adjoining surface. If this is a suitable host they will each produce a round disc like structure on the host bark (Fig. 8), under which penetration commences. This is the only purpose of this stage, to penetrate healthy 
host bark and connect with host cambial tissue below. It is another demonstration of the oddity of the oft-repeated instruction to place seed in a slit under host bark. Doing that would place the seed underneath the surface that it is perfectly adapted to connect to from above.

The 12 months following germination are mysterious, with nothing visible happening at all after the disc formation on the bark. If the disc has successfully linked to the host the seedling remains exactly the same, a tiny green growth bent from the seed husk to the host bark. If connection has failed the seedling turns brown and dies. Even in the second year, successful seedlings do very little, often merely straightening up, away from the seed remains. Over the following two or three years there will be some vertical lengthening and a pair of small leaves (Fig. 8), but there will be no dichotomous branching until about the fourth season, and usually no flowers (when the gender can be determined) until the fifth year. This slow initial start is frustrating for gardeners, who expect more rapid returns. But it also surprises many; I regularly get messages from people who had assumed failure, only to suddenly notice success five or six years later. When aging a mature plant by internode number an extra five years can be added to account for this lengthy seedling stage (unless the growth has arisen from a cortical strand - see below).

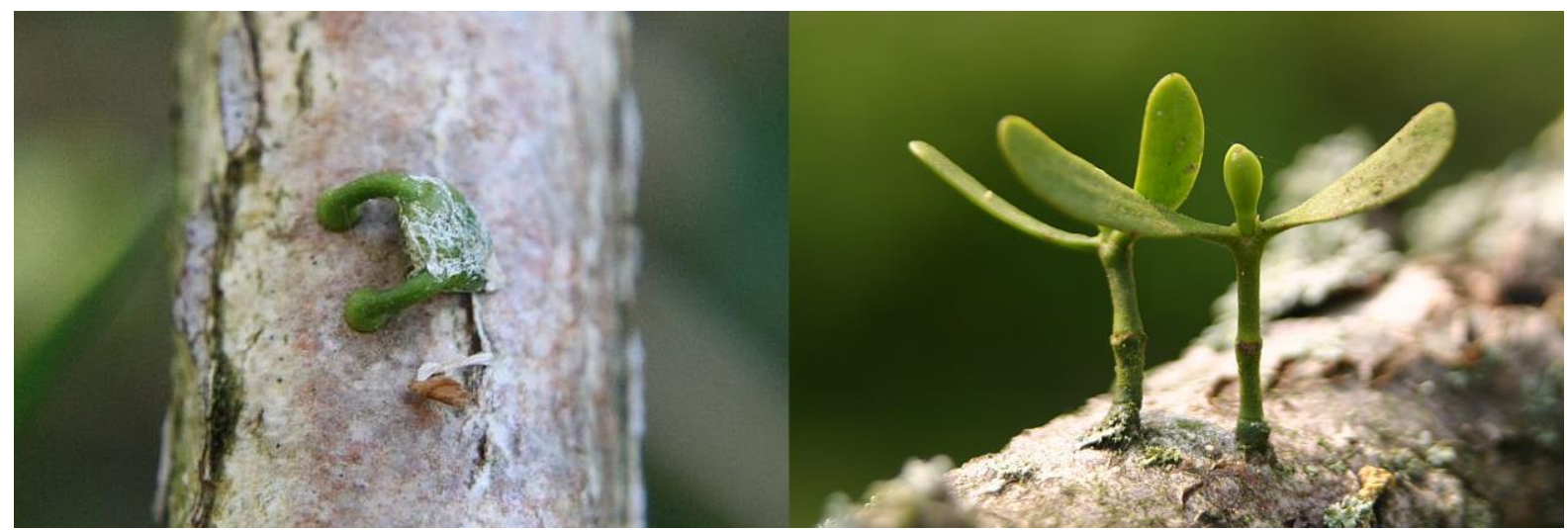

Figure 8. A germinating seed (left) showing twin hypocotyls bent onto the bark and holdfast discs forming. Twin 3-4 year old seedlings (right), the lowest internode being the original hypocotyls for each one.

\section{Connection to, and impacts on, the host}

The vascular link with the host, and the parasitic part of the plant's life, begins in the first year, underneath the disc formed by the seedling. There are many studies of this, including von Tubeuf (1923), Thoday (1951), Salle (1983). A tiny primary haustorium grows out from the seedling into the host bark, penetrating into the host cambial layer. Here a link is formed to the host xylem vessels, providing the seedling with water and mineral nutrients. The linkage develops and grows as the mistletoe stimulates future host xylem tissue to grow with it and around it. This creates, after a few years, a distorted host branch supporting a massive haustorium. Crosssections of this might suggest, at a glance, that the parasite has grown deep into the host wood. However, the deepest point of infection will still be where the initial cambial links were made. Everything else is subsequent growth around that point (Fig. 9). 
The primary haustorium also send shoots laterally; cortical strands that extend along the host cambial layer. These act like runners, enabling new growths at intervals further along the host branch. Each of these new growths will develop its own haustorium, not necessarily at the same depth as the original as there may be several growth cycles before they develop. The combination of the distortions around the primary haustorium, secondary haustoria and any adjoining but separate infections can produce quite complicated structures. The impact on the branches affected can be severe after a few years. These may cease to develop distally to the infection, with few or no leaves present. This is not a major problem when only a few branches are affected but can become critical with many infections.

Impacts are not, however, confined to the immediate branches affected. The vascular connection (xylem only, though there is some limited metabolite exchanges) can have implications for the whole host tree, especially in dry conditions. Most mistletoes, including $V$. album, have a higher transpiration rate than their hosts (Fisher, 1983), an adaptation that ensures they always have a favourable water status relative to the host. An additional complication for $V$. album subsp. album is ongoing transpiration through the winter months, when its deciduous host would not normally transpire.

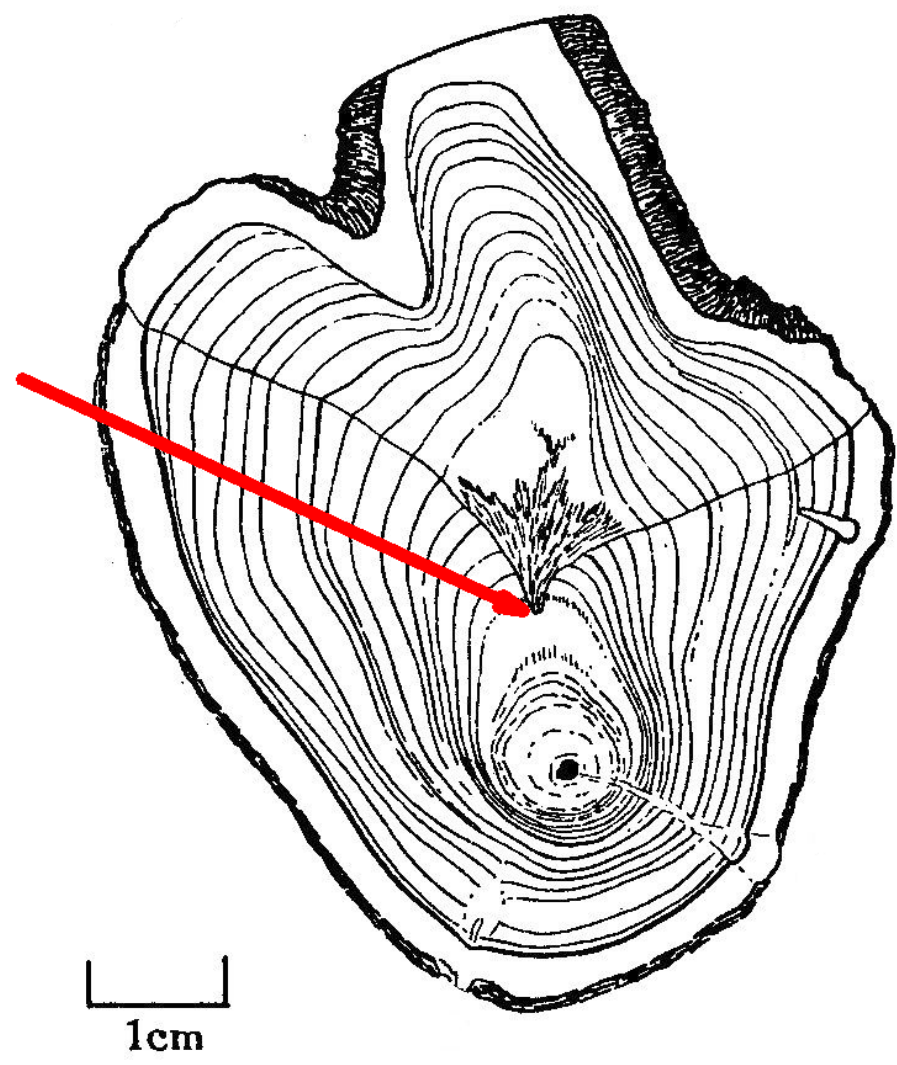

Figure 9. Cross-section through a Viscum album haustorium; transverse section of host (lower part of image) and longitudinal section of the parasite (upper part of image) showing how the haustorium distorts the host growth. The initial point of infection where the holdfast disc formed originally, is arrowed (after Thoday, 1956). 
Several recent studies confirm this transpiration behaviour. A study of infected poplars (Escher et al., 2008) found consistently high transpiration in V. album subsp. album, even when the host, under drought stress, was producing high levels of Abscisic Acid (ABA). ABA is a hormone produced to trigger closure of leaf stomata, but $A B A$ levels in the mistletoe were unaffected and mistletoe stomata remained open. The phenomenon also occurs in the $V$. album subspecies on evergreen hosts. A study of $V$. album subsp. austriacum on Pinus sylvestris $L$ in Switzerland (Zweifel et al., 2012) found that the mistletoe rarely closed its stomata even in severe drought conditions. The implications of this, for the host, go beyond water relations. For heavily infested hosts in dry periods the additional stress caused by $V$. album transpiration can result in further closure of host leaf stomata. This in turn reduces host gas exchange and photosynthesis. The annual growth pattern of $V$. album, doubling the leaf numbers each year, means that such impacts can increase exponentially year on year.

\section{Hosts}

Viscum album subsp. album has been recorded on a huge number of deciduous hosts and is considered to have a wider host range than any other mistletoe species worldwide. A literature review by Barney et al. (1998) identified 452 host taxa, across 92 genera in 44 families. The Rosaceae have the largest share overall. New reports of 'unusual' hosts are, mostly, not as remarkable as correspondents often think.

The widespread cultivation of $V$. album is a probable contributory factor to this host range. It has brought the species into contact with many hosts it would not encounter naturally. Some botanic gardens, particularly those at Oxford and at Cambridge, demonstrate this well, as V. album thrives at each on many exotic host taxa.

However, though the host range is wide, the frequency of occurrence on each is very different. The vast majority of infections occur over a very small group of taxa, particularly cultivars of Malus, Populus and Tilia. The dominance of just these few taxa, despite the wide range affected, implies that these are particularly susceptible to $V$. album infection. It is interesting that most of that small range is of hybrid or horticultural origin.

In the British Isles host frequency differs from continental Europe to some extent, with Betula and Acer more frequently recorded as hosts abroad. Here the primary hosts (Fig. 10) are domestic apple Malus domestica Borkh. cultivars, Hybrid Lime Tilia $x$ europeaus L., Hawthorn Crataegus monogyna Jacq. and Hybrid Black Poplar Populus $x$ canadensis Moench. Other taxa regularly recorded include numerous members of the Rosaceae including Sorbus, Mespilus, Chaenomeles, and Cotoneaster, plus many other genera including Acer and Salix. Quercus, as discussed above, is a rare host as are many other common trees including Fraxinus, Alnus and, in Britain, Betula. Unexpectedly frequent hosts include woody members of the Fabaceae such as Robinia.

Differing host susceptibility can be seen even with the frequent host range. Some apple cultivars, for example, seem rarely affected, even when in a mixed orchard surrounded by infected trees of other varieties. The opposite can be seen with Pear Pyrus communis L. and Plum Prunus domestica $\mathrm{L}$, both of which tend to 
be largely resistant to $V$. album. A susceptible pear or plum cultivar, with mistletoe, can sometimes be found amongst otherwise unaffected trees. Sometimes the difference can be striking. Near to my home in Gloucestershire there is an Acer avenue planted with alternate red- and green-leaved maple varieties (varietal names not determined) where only the red-leaved variety supports V. album (Briggs, 2013). A few studies have looked at these issues. For example, El Hariri et al. (1991) investigated differing mistletoe susceptibilities between Populus nigra 'Vereecken' and Populus trichocarpa 'Fritzi Pauley'. They found that 'Fritzi Pauley' was much more susceptible and attributed the resistance of 'Vereecken' to flavonoid levels in the host.

Garden lore often suggests host-specificity, arguing that Viscum album seeds will only grow on the same host as their parent. This is, fairly obviously, incorrect as V. album subsp. album readily colonises from taxon to taxon in both wild and cultivated environments. It even grows on taxa that, in the natural state, it would never have encountered. Yet, in apparent contrast to this, seeds from the subspecies on firs and pines are very definitely host specific. Our subspecies Viscum album subsp. album is, relatively-speaking, much less restricted in host range.

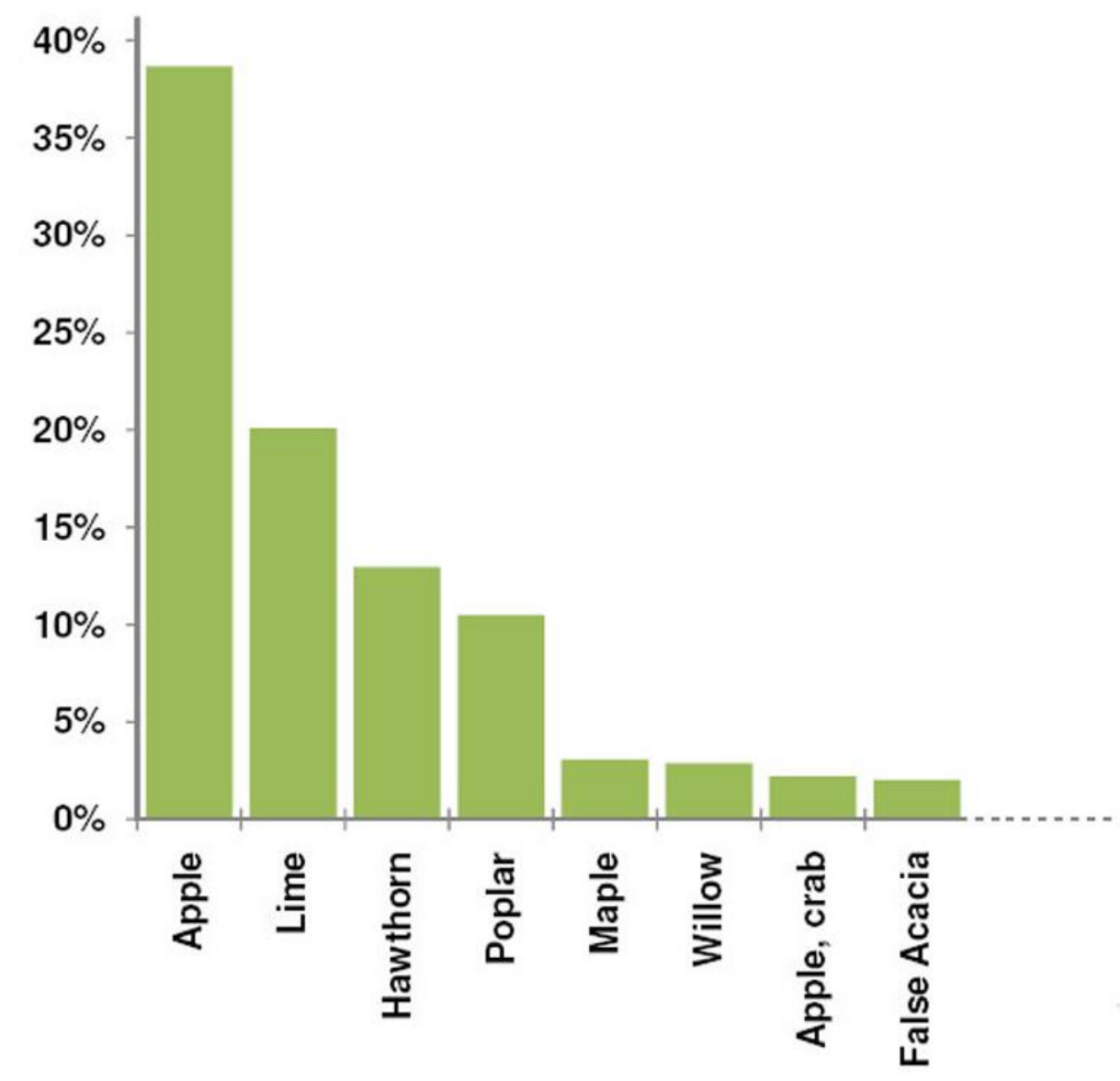

Figure 10. The main hosts in Britain, with proportion of records per host, a histogram from the 1990s survey (Briggs, 1999). 


\section{Habitats}

Despite $V$. album being a tree parasite, it is not, generally, considered a woodland species, at least not in Britain. Most infections here occur in trees in open situations, parkland, roadside or hedgerow tree, gardens, orchards, churchyards and woodland edges (Fig. 11). These are mostly artificial habitats, implying that $V$. album's frequency, in a wholly natural landscape, might be much more limited and perhaps confined to open woodland and alongside linear features such as watercourses or cliffs.

This habitat preference, coupled with the species' frequency on hybrid trees suggests that, in Britain at least, most $V$. album is dependent on planted trees in man-made habitats. This is an important consideration in any analysis of its current and future distribution.

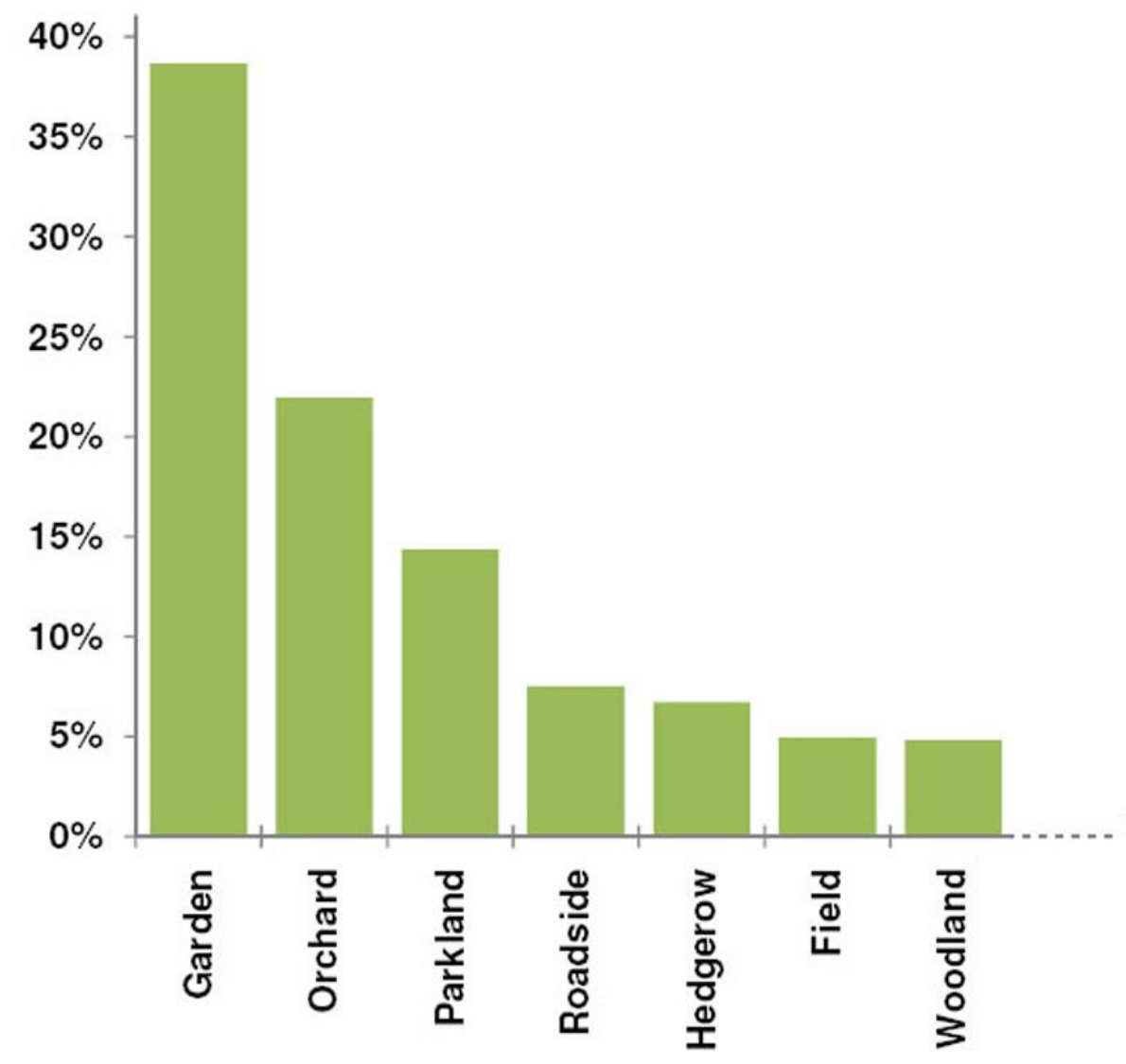

Figure 11. The main habitats in Britain, with proportion of records per habitat, a histogram from the 1990s survey (Briggs, 1999).

\section{Historic distribution}

In mainland Europe Viscum album is absent from more northerly latitudes, so is relatively uncommon in northern parts of Germany, Belgium, and most of the Netherlands. Its presence in Britain is therefore firstly notable for being further north than this, reflecting our oceanic climate. The second most striking feature is its distribution pattern within the British Isles, with a dense concentration in the southwest midlands of England (Fig. 1). It does occur more widely across the whole of England but only in isolated colonies, of hugely varying size. Some are just one or 
two plants, some a colony across one area of parkland, some cover several square miles. In Wales there is a significant concentration in the south-east, contiguous with the main England population across the border. Elsewhere in Wales and in Scotland and Ireland there are very few colonies but each one is, like the English colonies, variable in size and spread.

This odd distribution is well-known and long-established, highlighted in the 1970s study (Perring, 1973) and discussed in previous works, some a century before (e.g. Bull, 1864). It has been regarded, certainly until recently, as a fairly stable pattern. The 1990s study does, it should be noted, show many more locations than the 1970 s study but the underlying pattern is the same. Additional locations in the 1990s might be new sites or might simply reflect more recorder effort (Briggs, 1999, Rich, 2000). The 1990s data includes, for example, many records from private gardens that would have been unavailable previously.

The main distribution pattern is often assumed to relate to orchards, as the main range does coincide with a major apple-growing area. This assumption is, almost certainly, incorrect, not least as $V$. album is largely absent from other traditional apple-growing parts of the country. Distribution is much more likely to be linked to climate and geography, the species growing well in an area which, by coincidence, has numerous apple trees. This juxtaposition may have resulted in higher numbers of infections but, in theory at least, the distribution might look exactly the same without any apple orchards. It is interesting to note that numbers of habitats and hosts seems higher in the main range area than in other colonies across the country (Briggs, 1999, 2003).

Some direct geographical influences can be deduced from Figure 1. The relatively straight south-eastern side of the main range coincides with the Cotswold Escarpment, where height increases suddenly by 200 metres or so. This apparent preference for low altitudes can also be seen in Wales where the main range follows both the Usk and Wye valleys upstream. The upper Severn valley is also discernible to the north. Further south, in Somerset there is similar correlation, with an absence of records from the Mendips and other higher ground.

Altitude is, however, clearly not the factor limiting the species elsewhere across the country as colonies are spread across multiple altitudes. Climate is considered the major influence, with the south-west midlands presumably providing the best match for the species' needs. The main analysis available of those needs is by Iversen (1944) which, though often referenced and reiterated (e.g. Zuber, 2004) might seem over-simplistic, especially when the outlying colonies are considered. It suggests that the limiting factor for $V$. album is a need for high summer temperatures (at least $15^{\circ} \mathrm{C}$ ) and winter temperatures above $-8^{\circ} \mathrm{C}$. Relating this need to the distribution pattern in mainland Britain is difficult. Nelson (2008) observes that, for Ireland, none of the Irish locations fit the predicted need and concludes that this is why $V$. album does not thrive in Ireland. However, it does survive and spread in Ireland, albeit slowly. At least one colony (at Glasnevin, see below) is known to be well over 200 years old. Whatever the limiting factors are, they do not completely prohibit successful reproduction or spread.

This seems to be the case for most colonies outside the main range. They survive indefinitely, but do not seem to spread far. Many have their centres in large parks or gardens and are known to have existed for many decades, sometimes 
centuries. Dates of establishment, assuming deliberate planting, are frustratingly elusive, but those that have records are intriguing. These include Hampton Court, Richmond, where $V$. album, presumably introduced, has been known since at least the $18^{\text {th }}$ century and is now frequent across the grounds and adjoining Bushy Park. On the other side of London, in Enfield, an extensive colony of $V$. album across the Myddelton House and Forty Hall areas perhaps owes its existence to the botanist E A Bowles (1864-1954) a mistletoe enthusiast who lived there all his life. Several botanic gardens have long-established but slowly-spreading colonies, including those at Oxford and Cambridge. The botanic garden at Glasnevin, Dublin has had V. album since the mid $18^{\text {th }}$ century. It is now abundant within the garden and spread to adjoining streets and gardens (Nelson 2008). In Scotland there is an old colony at the Dean Cemetery, Edinburgh, where the species is said to have been introduced by William Paxton in the $19^{\text {th }}$ century. It is distinct from a small colony at Edinburgh Botanic Garden, about $1 \mathrm{~km}$ away to the north. A new colony found in 2015 (Junella MacKay pers. comm.) on two Sorbus trees in the roof-top garden of the nearby Glasshouse Hotel, may have originated from either (or been planted).

Such long-lived colonies outside the main range also occur abroad. Studies in Hamburg and Brussels, both just beyond the main continental distribution, show slow spread but long persistence. In Brussels (Olivier, 1998) there are longestablished populations in cemeteries around the city, with some recent expansion. In Hamburg (Poppendieck \& Petersen, 1999) populations established about 1903 were found to have spread only a few hundred metres.

Two introduced colonies of $V$. album in North America show marked contrasts, one spreading fast, as if in suitable climatic conditions, the other surviving but spreading slowly. The fast spreader is in Sonoma County, California, where it was introduced by Luther Burbank in about 1900. This has spread over a wide area, well over $100 \mathrm{~km}^{2}$, since (Hawksworth et al., 1991). In contrast a population much further up the west coast on Vancouver Island, British Columbia has spread to only a few trees despite being established for some decades (Job Kuijt, pers comm). In the USA further introductions of the species are prohibited under federal law.

\section{Changing distribution}

The status quo described above, with $V$. album thriving in the main range and limited elsewhere, seems to be changing. Many $V$. album populations well beyond the main range seem to be increasing, some of them quite dramatically. Though much of the evidence is anecdotal it is strongly consistent, suggesting very real change.

Formal studies have been undertaken in a few local areas. For example, in Essex and Redbridge, Vere (2008) records significant expansion of hitherto stable populations with 'explosive' expansion at three monitored sites. At Hampton Court, Richmond, Marris $(2007,2008)$ documented the expansion of the existing population including rapid colonisation of replacement limes, Tilia x europaea 'Koningslinde' from 1994 onwards. In Cambridge, Cadbury \& Oswald (2009) surveyed V. album within the city boundary, concluding that there was significant recent spread. In Suffolk, Kell (2020) reports a significant increase in infected trees since the 1990s.

Within the main range there may also be increasing spread with, visually at least, many more densely packed growths in habitats across the area. These include, 
unsurprisingly, old orchards, but also parkland limes and urban roadside trees. Proper measurement of change, though difficult, is discussed below.

In mainland Europe there are similar reports of increasing spread, sometimes on a large scale. In Ukraine Krasylenko et al. (2020) report 'rapid and remarkable expansion' in both natural and urban areas. In Hungary Varga et al. (2014) report a three-fold increase in infected areas over the last century. In the fir forests of Mount Parnis, Greece, Tsopelas et al. (2004) found increases in infections of $V$. album subsp. abietis.

Such changes may be due to one or more of several factors. At a basic level the exponential growth pattern of $V$. album should mean, in the absence of other influences, a doubling of available seeds every year. An 'explosive' increase after a number of years should be expected. Adding in the factor of management neglect, which is certainly the case for relict orchards and, as Tsopelas et al. (2004) suggest, for some fir forests too, such spread may be unchecked. A call for action because of uncontrolled spread in pine forests is highlighted, for Poland, by Szmidla et al. (2019).

Exponential growth may be less of a driver in some areas, particularly those colonies outside mistletoe's climatic norms. However, increasing spread is also being observed in such areas, implicating potential new factors such as climate change and, for Britain at least, changes in bird vectors.

The overwintering Blackcap phenomenon in Britain is well-documented. The species, a summer breeder, has changed its winter status from a rare overwinter visitor in the 1960s to an established and numerous winter visitor, present in nearly half the $10 \mathrm{~km}^{2}$ squares in Britain, by 2010. Possible reasons, including provision of bird-feeders, are discussed by Van Doren et al. (2021) who also summarise the history of the trend. Since, as discussed above, Blackcaps are very efficient $V$. album seed vectors their presence here will, surely, be increasing spread, certainly within the host or adjoining trees as they do not travel far to dispose of the seeds. More concentrated infections should be expected as a result.

Climate change (which may help explain the increase in over-wintering Blackcaps) might seem a longer-term factor but may already be playing a direct part. A modelling study of how climate change could affect $V$. album distribution was undertaken by Jeffree \& Jeffree (1996), based on Iversen's work (Iversen, 1944). Their modelling suggested, for Europe as a whole, a distributional shift northeastwards. For Britain the trend would be generally eastwards and could ultimately, if the climate model is correct, lead to the species' extinction in Britain.

Since several of the recent studies that show new spread in otherwise isolated colonies are in the east of Britain, it can be (somewhat loosely) speculated tha $t$ climate change may already be playing a direct role. Studies in Europe certainly suggest this is the case for some areas. In Switzerland Dobbertin et al. (2005) report that $V$. album subsp. austriacum is, following climate change, colonising pine trees at higher altitudes than previously.

\section{Biodiversity value}

Many mistletoes around the world are known to have closely associated species including birds, invertebrates and fungi. Some of the associations can quite significant, with large numbers of obligate invertebrate species in particular. Recent 
studies, mostly in Australia, have suggested that the influence of mistletoes can go beyond just those obligate associates, with mistletoe populations being a keystone resource within a habitat. Watson \& Herring (2012) describe an experimental approach on a woodland scale, comparing species richness from areas with mistletoes, areas with mistletoes deliberately removed and areas naturally without mistletoes. They found significant declines in species richness where mistletoe was removed. They suggested several possible factors, including the differing litter fall under mistletoe creating additional foraging.

For V. album there have been very few studies. Lázaro-González et al. (2017) review the differences between insect communities on $V$. album subsp. austriacum and its hosts Pinus nigra and $P$ sy/vestris, concluding that the mistletoe does increase the heterogeneity of the canopy. Within the British Isles there is only limited study, recording the obligate insect species on an ad hoc basis. Those found are all considered scarce or rare, but they may simply be under-recorded. Only one, the Mistletoe Marble Moth Celypha woodiana (Barrett), has been studied for conservation reasons. It is a Priority Species in the UK Biodiversity Action Plan (JNCC 2007).

In total six insects are fully dependent on $V$. album in Britain, though more obligates are known in continental Europe so others may be here un-noticed. Indeed, two of our six were only recorded in the last 20 years, suggesting either new colonisation from abroad or previous under-recording. The six, and their status, are reviewed in Briggs (2011a, b, c). In summary they are a plant-sucking homopteran, Cacopsylla visci (Curtis), two mirid bugs Pinalitus viscicola (Puton) and Hypseloecus visci(Puton), an anthocorid bug Anthocoris visci Douglas, a weevil Ixapion variegatum (Wencker) and the moth mentioned above. Hypseloecus visci was first recorded in Britain on orchard mistletoe in 2003 (Gibbs \& Nau, 2005) and Ixapion variegatum on orchard mistletoe in 2000 (Foster et al., 2001). Both of the newly recorded species have been recorded more widely since.

British accounts of these insects describe them as orchard specialists but that may be simply because $V$. album in orchards is easy to sample. The insects may be just as frequent on $V$. album in other habitats. Three of our six, for example, are found on V. album subsp. austriacum on Pine in Spain (Lázaro-González et al.,2017). There is evidence in Britain that all extend across the country and are present, even the 'new' species, on some of the otherwise isolated populations. This could suggest they have been transported, in overwintering form, in cut mistletoe, either across Britain and/or from abroad.

The studies of Celypha woodiana, a leaf-miner whose larvae overwinter in the leaves, suggest that it is more abundant where $V$. album growths are not overcrowded, i.e. it does not thrive in intense infections (Parsons \& McGill, 2010). This might make a UK policy case (as it is a UK Priority Species) for active management of $V$. album in over-infested trees.

The weevil, if truly new to Britain, could have implications for successful flowering and berry production. Eggs are laid just below each leaf pair and the larva develops inside the stem below the terminal flower bud, often causing that bud to die after adult emergence. If spreading as a new species it could gradually reduce flowering success, but if a long-established but overlooked native there may be a natural balance with no likely change. 
Other associates, such as fungi, have been little studied. Most older $V$. album growths show some evidence of black sporangia on senescent leaves and stems. Fallen leaves usually show the same black spots. These seem likely to be caused by Sphaeropsis visci (Fr.) Sacc. Nomenclature for this species is complicated by differing names for the anamorph and teleomorph stages. The species name for both forms was revised to Phaeobotryosphaeria visci (Kalchbr.) A.J.L. Phillips \& Crous by Philips et al., (2008) but Sphaeropsis visci was restored by Philips et al. (2013). A study by Varga et al. (2012) suggested the species might be used as a biological control for $V$. album. If the sporangia frequently seen are of this species it may be extremely common but proper study is needed.

Many more species of invertebrate and other groups, beyond the obligates discussed above, have been recorded using $V$. album, so the discussion could be broadened considerably, especially in the context of mistletoes being possible keystone resources.

\section{The seasonal mistletoe trade}

Other than for local customs and medicinal use mistletoe would, until the 19th century, have been a mere curiosity to most people. Anyone living outside its main range here would never even have seen it, perhaps not even heard of it. Within the main range it may have been viewed mainly as a pest of trees, reducing yield on fruit trees, distorting growth of others.

This changed hugely from the early 19th century onwards when the kissing custom, barely even mentioned before then, was popularised. The exact origin of the custom is obscure, but it presumably relates to some of the fertility symbolism of the plant. Whatever the origin the tradition was quickly adopted throughout Britain, taking its place alongside Christmas Trees, Christmas Cards and Santa Claus as part of the Victorian standardisation of Christmas. Charles Dickens' novel The Pickwick Papers (Dickens 1836), set in 1827-28, gives some prominence to the custom, with a party scene where many guests partake, shyly or boldly, after which Mr Pickwick himself is kissed by all the ladies present. It seems possible that this episode, in what became a very popular book, helped spread the custom more widely.

By the mid $19^{\text {th }}$ century $V$. album had definitely become a crop, a product in demand all over the country every December. The revolution in transport, particularly railways, helped its distribution. December issues of newspapers report mistletoe tonnages from the 1850s right through to the 1950s. Most British-grown mistletoe was sourced, unsurprisingly, from the south west Midlands where the growths on orchard apple trees were, compared to those high on limes or poplars, easy to harvest.

Demand was significant, and remained so until recent decades, when people seem to be less interested (or content themselves with plastic imitation kept from year to year). The trade was not (and still is not) particularly formally organised with most information coming from newspaper and magazine reports. These are fairly consistent throughout, with accounts of mistletoe laden railway wagons going to London markets and, intriguingly, much also going to ports for shipping to Canada, South Africa and even Australia. Our kissing custom, very much a British invention, was being exported all around the Empire. There are many reports of this from the 1880 s onwards. 
In 1938 several newspapers carried an account of Charles Johnson, a Cheltenham-based mistletoe trader nicknamed the 'Mistletoe King'. He told how he habitually sold large quantities of Severn Vale mistletoe to Covent Garden during November for export to the colonies, but that he stopped trading mistletoe completely in December as that was when the French imports began to arrive for domestic use. This is one of the most astonishing aspects of the mistletoe trade. It seems that our mistletoe-filled orchards never met domestic demand and much, maybe most, was (and perhaps still is) imported. Importing had begun long before Johnson's account, at least as early as the 1860s, with numerous accounts throughout the late $19^{\text {th }}$ century (Fig 12). The botanist W. Keble Martin, travelling on a mistletoe-laden ferry from France to England in 1895 recalled French fellowtravellers asking whether we ate it (Keble Martin, 1968). When a French law, passed in the 1890s, obliged French orchard owners to remove le Gui (mistletoe) from orchards to maximise fruit production the British press were aghast, predicting massive shortages of mistletoe from then on. No shortage ensued however and that law may well have led to more cross-channel trade. French farmers probably took full advantage of the requirement to cull their mistletoe.

\section{The quays of St Malo, Granville, and the other ports on the coast of Normandy and Brittany are at the present moment covered with immense crates full of mistletoe, for the decoration of English homes at Christmas time. It is said that from St. Malo alone the mistletoe onnually shipped to England is equal in volume to half the houses of the town.}

Figure 12. A press cutting from December1890, typical of the press stories each
December from the mid $19^{\text {th }}$ century through to the mid-20 $20^{\text {th }}$ century.

Demand was so high that accounts of seasonal theft, sometimes on a commercial scale, appear in cuttings throughout this period. An 1870 s account reports that railway trucks loaded with mistletoe in the West Country often arrived at Covent Garden only half full, as they were plundered at every stop along the line.

Exact figures for the trade are impossible to obtain, especially in recent years when much will have travelled informally with no documentation needed. The only data source readily available today is from Tenbury Wells, Worcestershire, where an annual wholesale mistletoe auction survives; echoing what might have been common in many market towns in the area at one time. These auctions there are consistently popular, with wholesalers travelling from all over the country to buy 
genuine 'English Mistletoe'. Though trade figures are available from here they may not be reliable indicators of trends or prices, as most mistletoe will be bought and sold in other ways, with much still imported. With that caveat aside, it is interesting to see what can be done with Tenbury data. For example, Ollerton et al. (2016) used Tenbury data in their discussion of the value of insect pollination, speculating that price fluctuations, year on year, reflect effectiveness of pollination in the preceding spring, stressing the importance of this for the Christmas crop. Their suggestion is sound, though one element of the analysis is questionable. As an attendee of those auctions for nearly 30 years I have to point out that their presumption that mistletoe lots classified as ' $2{ }^{\text {nd }}$ quality' had 'few if any berries' is incorrect. ' $2{ }^{\text {nd }}$ quality' lots include those that are less attractive, with yellower leaves or leggy branching, regardless of berry numbers. Any lots that do have fewer berries may have been adulterated with male sprigs (always berryless) to bulk them out. The sales classification is not, by itself, a measure of pollination success.

\section{The impact of harvest and trade}

The Christmas trade, giving V. album a value, has a significant influence on how it is managed. In orchards it becomes, to some extent, an asset, though still in need of management. The importance of this change of fortune is difficult to assess but it can be reasonably assumed that during the last 200 or so years $V$. album in Britain might have been tolerated more than it would have been otherwise. This tolerance presumably enabled more to grow, intensifying infections in the main range. Bull (1864), writing about Herefordshire, reports that $V$. album occurs, on average, on $39 \%$ of orchard apple trees, rising to $90 \%$ in 'old' orchards. Those figures, which seem high for managed orchards, may suggest deliberate tolerance.

The demand may also have been the catalyst for many of the deliberate plantings outside the main range, particularly by wealthy landowners in parks and gardens across the country. These may be the inoculums for many of the larger established isolated colonies we have today. There may well be some interesting provenance aspects to some of these colonies. With so much being imported from abroad it seems possible, likely even, that some are derived from berries brought in from the continent. There might, therefore, be significant genetic differences between some of them.

At a very local level, in orchards, there are other impacts. Management of excessive $V$. album, if done just to curtail growths, would logically involve removal of the infected limb, to eliminate regrowth and reduce infections from existing cambial strands. If management is carried out with harvesting in mind a different approach is taken, with the host branch generally left intact, and only the mistletoe stems being broken off for harvest. This approach sets the mistletoe back, giving the host some respite, especially from transpiration impacts, but enables the plant to re-grow for future harvest.

Allied to this is another other odd impact, often seen in orchards but also sometimes in gardens. Effective management requires pruning of all growths every few years. But harvesting for Christmas, though often considered a form of management, tends to only cut the female growths, the unberried male being valueless. This is poor management, often resulting in unchecked male growth. Some neglected orchards in the main $V$. album areas are now festooned with 
predominantly male plants, no longer even attracting seasonal harvesters as there are so few female plants. The phenomenon is particularly interesting considering that various studies (Showler, 1974, Stanton et al., 2009, others referenced in Zuber, 2004 and, recently in south Buckinghamshire, Harrison, 2019) have shown that natural, completely unmanaged, populations have a female bias.

\section{Conservation, control and planting projects}

Since the 1990 s there have been many initiatives to actively conserve $V$. album, primarily in areas where it is uncommon. This has been on the basis that the species is uncommon (in those areas) and has wider biodiversity value. Some are simply informal initiatives by Wildlife Trust and conservation groups, others are formal measures in local biodiversity plans. A few might, perhaps, be somewhat misguided, based on an erroneous belief that $V$. album in an area has become rare, when it may never have been common.

One of the Biodiversity Plan initiatives was in Greater London, where V. album was given an Action Plan in 2001 (now available via GiGL, 2007) on the basis of local rarity, cultural value and ease of monitoring. As discussed above there are two longestablished populations in the London area; around Richmond in the south-west and Enfield in the north-east. Between these areas, records were scattered and some known individual plants had been lost in recent years. The Action Plan for the species involved numerous new plantings, all in areas with some element of public management. These included Chelsea Physic Garden, various public parks in Kensington and Chelsea, a Royal Garden, the Natural History Museum Garden, a community orchard near Downe House, Bromley (to reflect Darwin's interest in mistletoe) and the Bishops Palace Garden in Lambeth. A review of these plantings is due soon. Some may already be at risk, it is not clear, for instance, whether the hitherto successful (NHM, 2012) Natural History Museum planting will survive the remodelling of the garden there.

In the same period there have been several marketing initiatives catering for gardeners who want to grow mistletoe. Mail-order berries with (mostly sensible) instructions have become readily available via the internet and may be increasing $V$. album incidence in private gardens. One of the earliest versions was from Nick Wheeldon, a Lincolnshire-based mistletoe enthusiast who sold berries with an instruction booklet from around 2002 onwards (Wheeldon, 2002). This was followed, in 2005, by a Grow-Your-Own Kit, marketed online by Tenbury English Mistletoe Enterprise (TEME, a business partnership I was part of) based on my experience of sowing and growing. This proved very popular, selling a few hundred a year until TEME was disbanded five years later. A similar concept, also with my involvement, has been marketed since via the online English Mistletoe Shop (EMS, 2021). Other online versions from rival sellers have become available in the same period, with operators including, for a few years at least, a supplier in the Netherlands.

Data from the EMS kit sales demonstrate the scale. Each kit contains berries freshly cut in February and March, with instructions to plant within two weeks of receipt. Over 2000 EMS kits have been sent out over the last decade to a wide mixture of gardeners, farmers, and conservation bodies. Figure 13 shows customer spread for the period 2013-21 in mainland Britain. There were over 200 orders in each year. Each $10 \mathrm{~km}$ square dot therefore represents a variable number of orders, 
ranging from just one or two for some of the Scottish locations, to several dozen for more southerly sites. It is noteworthy that there are relatively few orders coming from the main natural range of $\mathrm{V}$. album. Irish orders are not plotted but there were 10 to 15 per year until the UK left the EU Plant Health area in January 2021.

Whether these sales have impact on 'wild' distribution is not known. Figure 13 shows no obvious pattern, on the scale plotted, other than perhaps a bias to areas of higher population and, by implication, higher numbers of gardens. Not all plantings will be successful and, of those that are, it will be several years before the plant is flowering and fruiting. As discussed earlier isolated plants like these will take many years, decades probably, to spread even a short distance. It seems likely that successfully-sown mail-order plants will primarily remain in gardens, certainly in the short-medium term.

In complete contrast to the biodiversity and garden plantings it has become apparent, again in the same period, that there is a growing need for $V$. album control in many areas and circumstances. Many abandoned apple orchards in the main range are now heavily infested, a result of negligible management and/or more efficient bird vectors. Similar intensifications can be seen in other habitats in the area, for example the street trees of Cheltenham, always notable for $V$. album, seem to have much more now than a decade or so ago.

For the apple orchards in the main range such uncontrolled $V$. album growth results, eventually, in tree death. This does turn the premise of the 1990s survey that perhaps orchard loss was causing mistletoe decline - on its head. It now seems that excess mistletoe growth in neglected orchards is accelerating orchard loss.

The only solution is renewed management but, for heavily infested orchards, or indeed other habitats (including some neglected garden trees) this may be too impractical. Some orchard conservation groups, notably the Colwall Orchard Group in Herefordshire, have, through intensive cutting, managed to bring heavily infected orchards back into a viable condition. For over-infested orchards without such an effective conservation group the most pragmatic approach might be to leave the affected trees to senesce and die, replanting as needed and actively limiting infections on new trees to manageable levels. These problems are not unique to Britain. Many accounts of $V$. album spread and intensification elsewhere in Europe, some mentioned above, reference orchard and other habitat neglect as a major factor.

This crisis of control should, of course, be viewed in context. $V$. album in most situations, particularly actively managed habitats such as gardens or working orchards, is very easy to manage. It is a slow-growing plant that is easily pruned and whose prunings (the female branches at least) have a value every year. It only becomes a problem in situations, such as abandoned orchards, where there has been long-term neglect over several decades. 


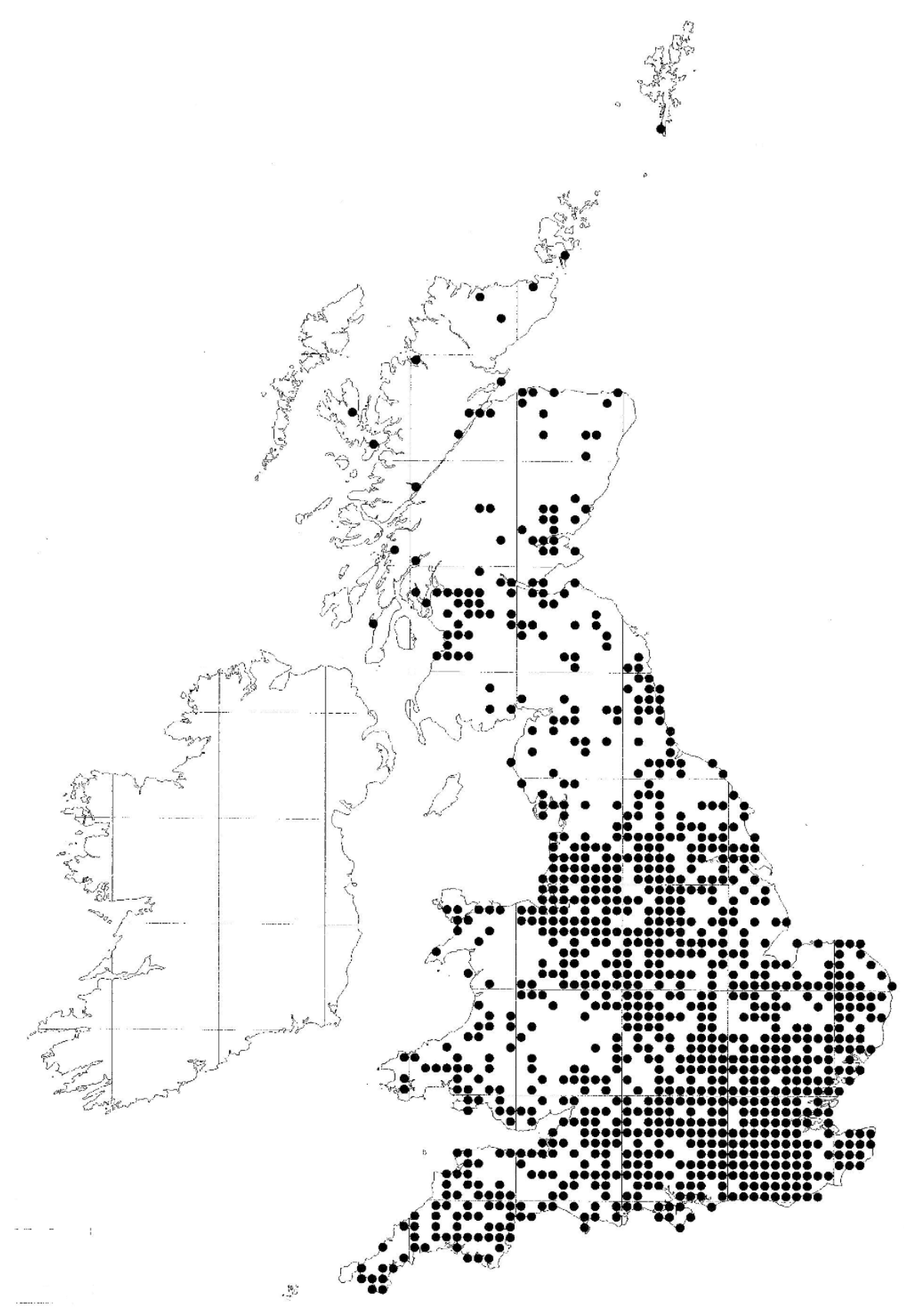

Figure 13. Distribution of customers ordering Mistletoe Growing Kits from the (online) English Mistletoe Shop between 2013 and 2021. The total number of orders represented is $\mathbf{2 1 8 5}$ spread across 8 seasons. The plot presented here is on a $10 \mathrm{~km}^{2}$ square scale. Some dots represent multiple customers, some only one or two. A similar number of orders were made in the 8 years previous to this. Note that Ireland, Isle of Man and Channel Island data are not shown.

\section{Toxicity, medicine and sub-cellular biology}

Viscum album is generally considered a toxic plant, with media articles every winter warning of the dangers of ingestion by children and pets. The actual risk is probably very small, as the various toxins, though quite potent, are not very concentrated without prior refinement. Indeed, the plant is actively sought by grazing animals as 
food, with any branches falling to the ground rapidly consumed by wild deer or by cattle or sheep. Sheep sometimes flock round mistletoe harvesters in a mistletoefilled orchard, snatching the crop from their hands as it is carried out. The plant, being evergreen, may be an important winter grazing resource when accessible. Indeed, there is evidence (Akeret \& Rentzel, 2001) and suggestion (Hejcman et al., 2014) that ancient farmers may have gathered mistletoe for feeding livestock in winter months. A recent study in Turkey actively investigated the species' potential for ruminant feed (Umucalılar et al., 2007). Despite such work the belief of most farmers today is that consuming V. album may cause health problems for livestock, particularly during pregnancy.

The toxicology of $V$. album is reviewed in Bussing (2000). The main toxins are viscotoxins, lectins and alkaloids. The lectins, cytotoxic proteins, are similar to Ricin, the lectin derived from Castor Oil Plant, Ricinus communis L. Ricin, used in some criminal poisonings (most famously in the killing of Bulgarian dissident Georgi Markov in 1978), is considered a possible terrorist weapon. In 2007 the V. album lectin known as Viscumin or ML-1 was added to Schedule 5 (the list of prohibited toxins, already including Ricin) of the UK Anti-terrorism, Crime and Security Act (National Archives, 2021). This implies that $V$. album could be used in terrorism. It puts the old Norse legend of Loki, the evil god who used mistletoe as a deadly weapon, into a very modern context.

With such potent chemicals it is not surprising that $V$. album has a long history of medicinal use. Throughout the centuries mistletoe material and potions have been used in a wide variety of remedies, particularly for epilepsy, nervous complaints, and hypertension. Such uses continue today in herbal medicines and, in continental Europe, in herbal teas. The most significant modern usage, also mainly in continental Europe, is in complementary cancer therapy. This treatment, with origins in Rudolf Steiner's belief that mistletoe should be a useful cancer medicine is widely used by practitioners of Steiner's anthroposophical medicine. Numerous commercially-branded $V$. album extracts are administered by injection and, in German-speaking countries, many thousands of cancer patients have had the therapy. Despite the popularity of the treatment, and numerous papers published by its advocates, it is not practiced much beyond those core areas. According to the American Cancer Society (2009); "available evidence from well-designed clinical trials does not support claims that mistletoe can improve length or quality of life". However, there is much literature, including many papers, by its advocates, mainly in German. English language reviews supporting the treatment include Gorter (1998), Murphy (2001), Wilkens and Bohm (2010) and the accounts within Bussing (2000). Dismissive critical reviews include Ernst (2006) and de Giorgio and Stebbing (2013). There is wider support for research showing that individual toxins (as opposed to injected plant extracts) may have anti-tumour properties.

Aside from toxicity and medical uses Viscum album has been shown, in studies from 2015 onwards, to have some very odd other peculiarities. Particularly the absence of a key respiratory process, previously thought essential to all eukaryotic organisms. Deficiencies discovered in the mitochondrial genome of some Viscum species (studies summarised in da Fonseca-Pereira, 2018) led to further investigation. Complementary projects by Maclean et al. (2018) and Senkler et al. (2018) found that in V. album this is linked to a complete absence of Complex I, the 
first of the 5-stage process needed for cell respiration. This process, universal in all multi-cellular eukaryotes, plant or animal, is a key part of aerobic respiration. $V$. album seems to compensate by adopting alternative energy generating reactions. It is not yet clear whether other mistletoe species have the same deficiency.

\section{Concluding discussion and research potential}

This paper has reviewed many aspects of $V$. album in the British Isles, alongside some European context and has, I hope, clarified many misunderstandings about the plant. Many of those are ongoing because of media attention each winter, which tend to highlight problems, regardless of accuracy. These include ongoing beliefs about difficulties in growing V. album and about its rarity. The 1990 s survey project, which speculated about $V$. album decline, may be partially responsible for this.

The more accurate news of $V$. album spread gets little coverage, and the actual problem with the inevitable long-term decline in harvestable supply as neglected orchards die seems too complicated for the media to grasp accurately. The broader conservation value of the species does, sometimes, get discussed.

All of these issues, whether talked about or not, are significant for the plant in Britain and there is a need to find out more about what is going on. There is clearly change afoot, with more growths and wider spread. Whether this change is due to simple mathematical explosion in numbers, changes in bird vectors, climate change or a mixture of all these factors is not known. Research projects could help determine the extent of change and might better identify the causes.

Viscum album is a wild plant but its wider distribution here is very clearly manmade, making it a very synanthropic species. Research could be done on the origins of the many isolated populations across the Britain and Ireland. Particularly whether records exist for their history, whether genetic structures vary, and whether there are identifiable genetic origins.

Studies of spread are challenging, as mere presence/absence is insufficient. They need to record host species and have some repeatable measure of quantity, either at a whole habitat scale, whole tree scale or whole mistletoe scale.

Several of the recent British studies have attempted this. Marris $(2007,2008)$ devised a system recording absence or presence per tree and, if present whether growths were single or multiple (this proved tricky for large growths). He also estimated the age of each growth, based on internode counts. Results, year on year, were fairly consistent with expectations. Vere (2008) used a theodolite to accurately measure diameters of each growth and then used data from these and observed internode lengths to extrapolate sizes and numbers of infections in other years.

In Greece Tsopelas et al. (2004) assessed V. album using the '6-class' system originally devised for dwarf mistletoes (Arceuthobium species) in North America. This system (Hawksworth, 1977) divides each tree into thirds vertically, rating each third as 0 for no mistletoe, 1 for less than half the branches infected and 2 for more than half the branches infected. A final infection score of 1-6 for each infected tree is derived by adding the thirds together. Trees without mistletoe score zero. The system can be used to produce an intensity of infection score for a stand of trees.

In India Rist et al. (2011) used an infection 'prevalence' measurement, the fraction of hosts infected for each survey plot. Krasylenko et al. (2020) discuss the possibilities of using drones to assess trees from above and also discuss using 
readily available online aerial photographs and Google Street View. The latter systems can, in my own experience, be extremely useful in checking locations for $V$. album but tend to only work well if the images were taken in winter, which often is not the case. Casual winter sightings whilst driving can even be recorded by dash cam (Mashanova, 2021).

The creation of an easily workable, and universally-used, system for Britain and Ireland would be useful for $V$. album assessments here, building a baseline to measure against in future. Rich (2000) discussing the 1990s survey, highlighted the need for a survey standard.

Dispersal studies would be useful too, not least getting hard data on whether Blackcaps really do spread seed better, though there is no baseline to compare to. Information on whether the Ring-necked Parakeets of Richmond are spreaders or not would also be interesting.

More information on the precise climatic requirements of $V$. album would, obviously, also be useful, as would updated climate modelling. To be fully accurate that would need a Europe-wide study but local studies on reasons for the success, or otherwise, of the spread of isolated populations in sub-optimal areas would help. Some local studies abroad have suggested correlations, in urban areas, with air pollution (e.g. Kolodziejek et al.,2013 who found a correlation of $V$. album populations with nitrogen oxide pollution).

The obligate and other associated species could also be researched. Little is known of these as they are rarely recorded and, when they are, only cursory observations (little more than recording presence) are made. These may have relevance to $V$. album spread - the weevil, in damaging flower buds, might help control it. One of the fungi has been suggested as a control. The moth, apparently, only thrives in well-managed mistletoe. The role of insects in V. album pollination, including any limiting factors that might affect success, could also be looked into more. Also, the wider conservation value of $V$. album for associates deserves some attention, particularly in the context of 'keystone' species.

Alongside any research there are the ongoing issues of planting, conservation and, where needed, control. The species is very popular as a curiosity, conservation resource, and seasonal crop. Conservation and garden plantings may, in their own way, be slowly changing distribution, continuing a long tradition going back two centuries. This should perhaps be monitored somehow. Where there is excess and neglected growth, particularly in the main range, there is a management need, which, though often difficult to implement, should at least be better communicated.

What is, I hope, clear from all of the above, is that the simplistic premise of the 1990s survey, that orchard decline might be threatening V. album, was certainly naive. The answer to the question raised in the title of the survey report (Briggs, 1999) "Kissing Goodbye to Mistletoe?" is, at present, a very definite No. Not yet anyway.

\section{Acknowledgements}

I am grateful to innumerable people for mistletoe discussions and projects over several decades, some of whose work is referenced. I have tried to include a representative cross-section of published work, but have inevitably omitted some for lack of space. Particular thanks go to Caroline Tandy for her support on numerous 
mistletoe expeditions and initiatives and for her forbearance whilst I compiled this paper during 2021.

\section{References}

Akeret, O. \& Rentzel, P. 2001. Micromorphology and Plant Macrofossil Analysis of Cattle Dung from the Neolithic Lake Shore Settlement of Arbon Bleiche 3. Geoarchaeology 16(6): 687-700. Available at: <doi.org/10.1002/gea.1016>

American Cancer Society. 2009. Complete Guide to Complementary \& Alternative Cancer Therapies. Atlanta: American Cancer Society.

Barney, C., Hawksworth, F. \& Geils, B. 1998. Hosts of Viscum album. European Journal of Forest Pathology 28: 187-208.

Box, J.D. 2000. Mistletoe Viscum album L. (Loranthaceae) on oaks in Britain. Watsonia, 23: 237-256. Available at: $<$ http://archive.bsbi.org.uk/Wats23p237.pdf>

Box, J. 2019. Oaks (Quercus spp.) parasitised by mistletoe Viscum album (Santalaceae)in Britain. British \& Irish Botany 1(1): 39-49. Available at: $<$ https://doi.org/10.33928/bib.2019.01.039>

Bussing, A., ed. 2000. Mistletoe: The Genus Viscum (Medicinal and Aromatic Plants Industrial Profiles). Amsterdam: Harwood Academic.

Briggs, J. 1996. Mistletoe - distribution, biology and the National Survey. British Wildlife 7: 75-82.

Briggs, J. 1999. Kissing Goodbye to Mistletoe? Plantlife/BSBI report.

Briggs, J. 2003. Christmas curiosity or medical marvel? A seasonal review of mistletoe. Biologist 50(6): 249-254.

Briggs, J. 2007. Mistletoe Survey - help needed for final analysis. BSBI News 106: 41. Available at: <https://archive.bsbi.org/BSBINews106.pdf>

Briggs, J. 2011a. Mistletoe - a review of its distribution, conservation and insect associates. British Wildlife 23: 23-31.

Briggs, J. 2011b. Mistletoe (Viscum album); a brief review of its local status with recent observations on its insect associations and conservation problems. Proceedings of the Cotteswold Naturalist Field Club, XLV (II): 181-193.

Briggs, J. 2011c. Mistletoe and mistletoe insects, overview and observations from 2010. Worcestershire Record 30: 9-15. Available at: $<$ http://www.wbrc.org.uk/WORCRECD/issue 30/Briggs Jonathan-Mistletoe and mistletoe insects overview and observations from 2.html>

Briggs, J. 2012. Mistletoe on the move Biologist 59(5): 24-27.

Briggs, J. 2013. Zig-zag mistletoe - red v. green maples. [Online blog]. Available at: $<$ https://mistletoediary.com/2013/12/29/zig-zag-mistletoe-red-v-greenmaples $>$

Briggs, J. 2014. Mistletoe seeds dream of a Light Christmas. [Online blog]. Available at: <https://mistletoediary.com/2014/12/20/mistletoe-seeds-dream-of-a-lightchristmas/>

Briggs, J. 2019. Viscum album (Mistletoe) - with or without hot-spots. BSBI News 142: 28-30.

Bull, H. G. 1864. The Mistletoe in Herefordshire. Transactions of the Woolhope Naturalists Field Club 5: 59-108. 
Cadbury, C.J. \& Oswald P.H. 2009. Mistletoe (Viscum album) undergoes an explosive increase in Cambridge. Nature in Cambridgeshire 51: 50-60. Available at: $<$ https://www.natureincambridgeshire.org.uk/volumes/nature-in-cambs-vol-512009.pdf $>$

Dickens, C. 1836. The Pickwick Papers. Available at: https://www.gutenberg.org/files/580/580-h/580-h.htm

Dobbertin. M., Hilker, N., Rebetez, M., Zimmermann, N.E., Wohlgemuth, T. \& Riglin, A. 2005. The upward shift in altitude of pine mistletoe (Viscum album ssp.austriacum) in Switzerland - the result of climate warming? International Journal of Biometeorology 50: 40-47. Available at: < doi.org/10.1007/s00484005-0263-5>

Edwards, H.G.M., Montgomery J., Melton, N.D., Hargreaves, M.D, Wilson, A.S \& Carter, E.A. 2009, Gristhorpe Man: a Raman spectroscopic study of 'mistletoe berries' in a Bronze age log coffin burial, Journal of Raman Spectroscopy 41: 1533-1536. Available at: <doi.org/10.1002/jrs.2593>

EMS, 2021. Mistletoe Grow-Kits. Available at:

https://englishmistletoeshop.co.uk/live/?product=mistletoe-grow-kit

Ernst, E. 2006. Mistletoe as a treatment for cancer. British Medical Journal 333: 1282-1283. Available at:

https://www.bmj.com/content/bmj/333/7582/1282.full.pdf>

Escher, P., Peuke, A.D., Bannister, P., Fink, S., Hartung, W., Jiang, F. \& Rennenberg, H. 2008. Transpiration, $\mathrm{CO} 2$ assimilation, WUE, and stomatal aperture in leaves of Viscum album L: Effect of abscisic acid (ABA) in the xylem sap of its host (Populus $x$ euamericana). Plant Physiology and Biochemistry 46: 64-70. Available at: <doi.org/10.1016/j.plaphy.2007.07.018>

Fisher, J. 1983. Water Relations of Mistletoes and their Hosts. In: Calder M. \& Bernhardt, P., eds. The Biology of Mistletoes 161-184. Sydney: Academic Press. da Fonseca-Pereira, P., Batista Silva, W.B., L. Araújo, W.L. \& Nunes-Nesi, A. 2018. How Does European Mistletoe Survive Without Complex I? Trends in Plant Science 23(10): 847-850. Available at: $<$ doi.org/10.1016/j.tplants.2018.07.008>

Foster, A.P., Morris, M.G., \& Whitehead, P.F. 2001. Ixapion variegatum (Wenker), (Coleoptera, Apionidae) new to the British Isles, with observations on its European and conservation status. Entomologist's Monthly Magazine 137: 95105.

Frazer, J. G. 1890. The Golden Bough: A Study in Comparative Religion. London: Macmillan.

Gibbs, D. \& Nau, B. 2005. Hypsoloecus visci (Puton) (Hemiptera: Miridae) a mistletoe bug new to Britain. British Journal of Entomology and Natural History 18: $159-161$.

GiGL. 2007. Mistletoe Action Plan for Greater London [update of original 2001 Plan] Available at: http://downloads.gigl.org.uk/website/Mistletoe\%20Action\%20Plan.pdf

de Giorgio A, Stebbing J. 2013. Mistletoe: for cancer or just for Christmas? Lancet Onco/ 2013: 13: 1264-65 Available at: <https://www.sciencedirect.com/science/article/pii/S1470204513705606>

Gorter, R.W. 1998. Iscador. Basel: Verlag fur Ganzheits Medizin. 
Guerin, F.J. 1903. Germination et Implantation du Gui. Haarlem: De Erven Loosjes.

El Hariri, B., Sallé, G. \& Andary, C. 1991. Involvement of flavonoids in the resistance of two poplar cultivars to mistletoe (Viscum album L.) Protoplasma 162: 20-26.

Harrison, T. 2019. Viscum album hot-spots and not-spots in south Buckinghamshire. BSBI News 141: 19-21.

Hatton, R.H.S. 1964. Pollinaton of Mistletoe (Viscum alba L.). Proceedings of the Linnean Society of London 176: 67-76.

Hawksworth, F.G. 1977. The 6-Class Dwarf Mistletoe Rating System. USDA Forest Service General Technical Report RM-48. Available at: $<$ https://openlibrary.org/books/OL17539893M/The 6class dwarf mistletoe rating system $>$.

Hawksworth, F.G., Scharpf, R.F. \& Marosy, M. 1991. European mistletoe continues to spread in Sonoma County. California Agriculture 45: 39-40.

Heide-Jorgensen, H. 2008. Parasitic Flowering Plants Leiden: Brill.

Hejcman, M., Hejcmanová, P., Stejskalová, M. \& Pavlů, V. 2014. Nutritive value of winter-collected annual twigs of main European woody species, mistletoe and ivy and its possible consequences for winter foddering of livestock in prehistory. Holocene 24(6): 659-667. Available at: $<$ doi.org/10.1177/0959683614526904>

Hutton, R. 2009. Blood \& Mistletoe: The History of the Druids in Britain. New Haven, Connecticut: Yale University Press.

Iversen, J. 1944. Viscum, Hedera and Ilex as climate indicators. Geologiska Foreningens I Stockholm Forhandlingar 66: 463-483.

JNCC. 2007. List of UK BAP Priority Terrestrial Invertebrate Species. 2007. Available at: <https://data.jncc.gov.uk/data/98fb6dab-13ae-470d-884b7816afce42d4/UKBAP-priority-terrestrial-invertebrates.pdf>

Jeffree, C.E. \& Jeffree, E.P. 1996. Redistribution of the potential geographic ranges of Mistletoe and Colorado Beetle in Europe in response to the temperature component of climate change. Functional Ecology 10: 562-577.

Joy, J. 2009. Lindow Man. London: British Museum Press.

Kay, Q. 1989. Mistletoe has problems too. Plants Today, Jan-Feb 1989.

Keble Martin, W. 1968. Over The Hills. London: Michael Joseph.

Kell, A. 2020. Viscum album (Mistletoe) - a preliminary survey in Suffolk. BSBI News 143: 25-28.

Kołodziejek, J., Patykowski, J. \& Kołodziejek, R. 2013. Distribution, frequency and host patterns of European mistletoe (Viscum album subsp. album) in the major city of Lodz, Poland. Biologia 68/1: 55-64. Available at:

$<$ doi.org/10.2478/s11756-012-0128-4>

Krasylenko, Y., Sosnovsky, Y., Atamas, N., Popov, G., Leonenko, V., Janošíková, K., Sytschak, N., Rydlo, K. \& Sytnyk, D. 2020. The European Mistletoe (Viscum album L. ); distribution, host range, biotic interactions, and management worldwide with special emphasis on Ukraine. Botany 98: 499-516. Available at: $<$ doi.org/10.1139/cjb-2020-0037>

Lázaro-González, A., Hódar, J.A. \& Zamora, R. 2017. Do the arthropod communities on a parasitic plant and its hosts differ? European Journal of Entomology 114: 215-221. Available at: <doi.org/10.14411/eje.2017.026> 
Lockwood W.B. 1984. Oxford Book of British Bird Names. Oxford: Oxford University Press.

Maclean, A., Hertle, A., Ligas, J., Bock, R., Balk, J. \& Meyer, E. 2018. Absence of Complex I Is Associated with Diminished Respiratory Chain Function in European Mistletoe. Current Biology 28: 1614-1619.

Marris, T. 2007. Survey of mistletoe Viscum album platyspermum at Hampton Court Palace. The London Naturalist 86: 35-46.

Marris, T. 2008. A further survey of mistletoe Viscum album platyspermum at Hampton Court Palace. The London Naturalist 87: 53-56.

Mashanova, A. 2021. Using dash cams for recording plants on road verges. BSBI News 146: 32-33.

Mellado, A. \& Zamora, R. 2014. Generalist birds govern the seed dispersal of a parasitic plant with strong recruitment constraints. Oecologia 176: 139-147. Available at: <doi.org/10.1007/s00442-014-3013-8>.

Murphy, C. ed. 2001. Iscador: Mistletoe and Cancer Therapy. New York: Lantern Books.

NHM. 2012 .Winter Solstice Species. Available at: $<$ https://www.nhm.ac.uk/natureplus/blogs/wildlife-garden/2012/12/18/wintersolstice-species.html>

National Archives. 2021. Anti-terrorism, Crime and Security Act 2001, Changes over time for Schedule 5. Available at: <https://www.legislation.gov.uk/ukpga/2001/24/schedule/5/2007-04-02>

Nelson, E.C. 2008. Mistletoe (Viscum album) in Ireland: a review of records and status. Irish Naturalists Journal 29: 87-94.

Olivier, J-F. 1998. Cartographie de Viscum album a Bruxelles et dans les environs Adoxa 20/21: 1-14.

Ollerton, J., Rouquette, J.R. \& Breeze, T.D. 2016. Insect pollinators boost the market price of culturally important crops: holly, mistletoe and the spirit of Christmas. Journal of Pollination Ecology 19: 93-97.

Parsons, M. \& McGill. 2010. Celypha woodiana (Barrett) (Lep.: Tortricidae) - An update. Entomologists Record and Journal of Variation 122: 49-52. Available at: https://ptes.org/wp-content/uploads/2016/07/Parsons-McGill.pdf

Perring, F. 1973. Mistletoe. In: Green, P.S., ed. Plants wild and cultivated, 139-145. London: BSBI.

Phillips, A., Alves, A., Pennycook, S., Johnston, P., Ramaley A., Akulov, A. \& Crous, P. 2008. Resolving the phylogenetic and taxonomic status of dark-spored teleomorph genera in the Botryosphaeriaceae. Persoonia 21: 29-55. Available at: < doi.org/10.3767/003158508X340742>

Phillips, A., Alves A., Abdollahzadeh J., Slippers B., Wingfield M.J., Groenwald J.Z., Crous P.W. 2013. The Botryosphaeriaceae: genera and species known from culture. Studies in Mycology 76: 51-167. Available at: $<$ doi.org/10.3114/sim0021>

Poppendieck H. \& Petersen J. 1999. Ein ausbreitungsbiologisches LangzeitExperiment: Die Einburgerung der Mistel in Hamburg und Umgebung. Abhandlungen herausgegeben vom Naturwissenschaftlichen Vereins zu Bremen 44/2-3: 377-396. 
Rich, T.C.G. 2000. A reanalysis of the Mistletoe (Viscum album L.: Loranthaceae) survey data from the 1970s and 1990s. Watsonia 23: 338-339. Available at: $<$ http://archive.bsbi.org.uk/Wats23p335.pdf>

Rist, L.; Uma Shaanker, R. \& Ghazoul, J. 2011. The Spatial Distribution of Mistletoe in a Southern Indian Tropical Forest at Multiple Scales: Spatial Distribution of a Tropical Mistletoe. Biotropica 43: 50-57. Available at: < doi.org/10.1111/j.17447429.2010.00643.X>

Ross, A. \& Robins, D. 1989. The Life and Death of a Druid Prince. New York: Summit Books.

Salle, G. 1983. Germination and Establishment of Viscum album L. In: Calder M. \& Bernhardt, P., eds. The Biology of Mistletoes 145-159. Sydney: Academic Press.

Senkler, J., Rugen, N., Eubel, H., Hegermann, J., \& Braun, H. 2018. Absence of Complex I Implicates Rearrangement of the Respiratory Chain in European Mistletoe. Current Biology 28(10): 1606-1613.

Showler, K. 1974. Raising mistletoe (Viscum album) from seed. Journal of the Royal Horticultural Society 99: 30-37.

Snow, B. \& Snow, D. 1988. Birds and Berries. London: Poyser.

Stanton, S., Boavida Torrado, S.B. \& Honnay, O. 2010. Seed germination tests of the parasitic perennial Viscum album (Viscaceae) from fragmented habitats at the northern edge of its range. Plant Ecology and Evolution 143: 113-118. Available at: https://doi.org/10.5091/PLECEVO.2010.413

Stauffer, R.C. ed. 1975. Charles Darwin's Natural Selection; being the second part of his big species book written from 1856 to 1858. Cambridge: Cambridge University Press. Available at: <http://darwinonline.org.uk/content/frameset?\&pageseq $=1$ \&itemID $=F 1583 \&$ viewtype $=$ text $>$

Szmidla, H., Tkaczyk, M., Plewa, R., Tarwacki, G. \& Sierota, Z. 2019. Impact of Common Mistletoe (Viscum Album L.) on Scots Pine Forests - A Call For Action. Forest 10(10): 847. Available at: <doi.org/10.3390/f10100847>

Thoday, D. 1951. The Haustorial System of Viscum album. J Experimental Botany 2(1): 1-19.

Thoday, D. 1956. Modes of union and interaction between parasite and host in the Loranthaceae: I Viscoideae, not including Phoradendreae. Proceedings of the Royal Society Series B 145: 531-548.

Thomas, P.A. et al. Biological Flora of the British Isles: Viscum album. Journal of Ecology (in preparation).

Tsopelas, P., Angelopoulos, A., Economou, A. \& Soulioti, N. 2004. Mistletoe (Viscum album) in the fir forest of Mount Parnis, Greece. Forest Ecology and

Management 202: 59-65. Available at: $<$ doi.org/10.1016/j.foreco.2004.06.032>

Umucalılar, D.,, Gülşen, N., Coşkun, B., Hayirli, A., \& Dural, H. 2007. Nutrient composition of mistletoe ( Viscum album) and its nutritive value for ruminant animals. Agroforestry Systems 71(2): 77-87. Available at: $<$ doi.org/10.1007/s10457-007-9089-y>

Van Doren, B.M., Conway, G.J., Phillips, R.J., Evans, G.C., Roberts, G.C.M., Liedvogel, M. \& Sheldon, B.C. 2021. Human activity shapes the wintering ecology of a migratory bird. Global Change Biology 27: 2715-2727. Available at: < doi.org/10.1111/gcb.15597> 
Varga, I., Taller, J., Baltazár, T., Hyvonen, J. Poczai, P. 2012. Leaf-spot disease on European mistletoe (Viscum album) caused by Phaeobotryosphaeria visci: a potential candidate for biological control. Biotechnology Letters 34: 1059-1065. Available at: <doi.org/10.1007/s10529-012-0867-x>

Varga I., Poczai P., Tiborcz, V., Aranyi, N.R., Baltazár, T., Bartha, D., Pejchal, M. \& Hyvönen, J. 2014. Changes in the Distribution of European Mistletoe (Viscum album) in Hungary During the Last Hundred Years. Folia Geobotanica 49: 559577. Available at: <doi.org/10.1007/s12224-014-9193-5>.

Vere, D.W. 2008. A numerical analysis of the recent spread of mistletoe Viscum album in Essex and north-east London. The London Naturalist 87: 57-64.

Vickery, R. 1995. A Dictionary of Plant-Lore. Oxford: Oxford University Press.

von Tubeuf, K. 1923. Monographie der Mistel. Munich and Berlin: Oldenbourg Verlag.

Watson D.M. \& Herring, M. 2012. Mistletoe as a keystone resource: an experimental test. Proceedings of the Royal Society Series B 279: 3853-3860. Available at: $<$ doi.org/10.1098/rspb.2012.0856>

Watson, D.M. 2013. The Relative Contribution of Specialists and Generalists to Mistletoe Dispersal: Insights from a Neotropical Rain Forest. Biotropica 45: 195202. Available at: <迆.org/10.1111/j.1744-7429.2012.00905.x>

Wheeldon, N. 2002. Grow Your own Mistletoe. Privately published.

Wilkens, J. \& Bohm, G. 2010. Mistletoe Therapy for Cancer. Edinburgh: Floris Books. Zuber, D. 2004. Biological flora of Central Europe: Viscum album L. Flora 199: 181203. Available at: <doi.org/10.1078/0367-2530-00147>.

Zweifel, R., Bangerter, S., Rigling, A. \& Sterck, F. 2012. Pine and mistletoes: how to live with a leak in the water flow and storage system? Journal of Experimental Botany 63: 2565-2578. Available at: < doi.org/10.1093/jxb/err432>

Copyright retained by author(s). Published by BSBI under the terms of the Creative Commons Attribution 4.0 International Public License.

ISSN: $2632-4970$

https://doi.org/10.33928/bib.2021.03.419 